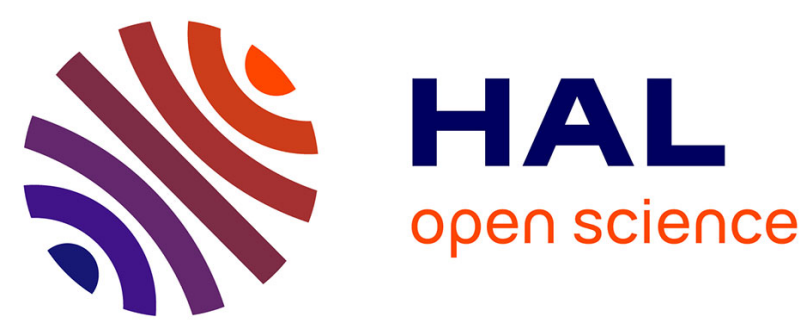

\title{
Comparison of Surface Water-Groundwater Exchange Fluxes Derived From Hydraulic and Geochemical Methods and a Regional Groundwater Model
} Camille Bouchez, Peter G Cook, Daniel Partington, Craig T. Simmons

\section{- To cite this version:}

Camille Bouchez, Peter G Cook, Daniel Partington, Craig T. Simmons. Comparison of Surface Water-Groundwater Exchange Fluxes Derived From Hydraulic and Geochemical Methods and a Regional Groundwater Model. Water Resources Research, 2021, 57 (3), pp.e2020WR029137. 10.1029/2020WR029137 . insu-03163350

\section{HAL Id: insu-03163350 \\ https://hal-insu.archives-ouvertes.fr/insu-03163350}

Submitted on 9 Mar 2021

HAL is a multi-disciplinary open access archive for the deposit and dissemination of scientific research documents, whether they are published or not. The documents may come from teaching and research institutions in France or abroad, or from public or private research centers.
L'archive ouverte pluridisciplinaire HAL, est destinée au dépôt et à la diffusion de documents scientifiques de niveau recherche, publiés ou non, émanant des établissements d'enseignement et de recherche français ou étrangers, des laboratoires publics ou privés. 


\section{Water Resources Research}

\section{RESEARCH ARTICLE \\ 10.1029/2020WR029137 \\ Key Points: \\ - On the regional scale, the surface \\ Comparison of Surface Water-Groundwater Exchange Fluxes Derived From Hydraulic and Geochemical Methods and a Regional Groundwater Model} water-ground water (SW-GW) exchange fluxes estimated by three methods differ both in direction and magnitude

- Flow direction and its temporal variability are indicated by hydraulic heads, tracer mass balance gives flow magnitude in gaining reaches

- Missing data yield a poor calibration of the regional scale numerical model and erroneous SW-GW fluxes in losing reaches

Supporting Information:

- Supporting Information S1

Correspondence to:

C. Bouchez,

camille.bouchez@univ-rennes1.fr

Citation:

Bouchez, C., Cook, P. G., Partington, D., \& Simmons, C. T. (2021). Comparison of surface water-groundwater exchange fluxes derived from hydraulic and geochemical methods and a regional groundwater model. Water Resources Research, 57, e2020WR029137. https:// doi.org/10.1029/2020WR029137

Received 30 OCT 2020 Accepted 28 JAN 2021

(C) 2021. American Geophysical Union. All Rights Reserved.

\author{
Camille Bouchez $^{1,2}$ (D) Peter G. $\operatorname{Cook}^{1}$ (D), Daniel Partington ${ }^{1}$ (D), and Craig T. Simmons ${ }^{1}$ (i) \\ ${ }^{1}$ National Centre for Groundwater Research and Training and the College of Science and Engineering, Flinders \\ University, Adelaide, SA, Australia, ${ }^{2}$ Univ Rennes, CNRS, Géosciences Rennes, Rennes, France
}

\begin{abstract}
Intercomparison of surface water-groundwater (SW-GW) exchange fluxes at the regional scale is rarely undertaken, mainly because estimates are method and scale-dependent and usually associated with large errors. In the present study, we compare SW-GW exchange fluxes calculated from a multitracer mass balance in the river, an application of Darcy's law using near-river piezometers and a surface-subsurface flow model calibrated at the catchment scale. SW-GW exchange fluxes are estimated for $7 \mathrm{~km}$ long reaches along the $140 \mathrm{~km}$ long Campaspe River, a tributary of the Murray River, Australia. Differences are found in the directions and magnitudes of the exchange fluxes estimated by the different methods. The application of Darcy's law in near-river piezometers seems the most appropriate method to infer SW-GW flow directions and temporal variability. The tracer mass balance is limited to gaining reaches but gives quantitative estimates of the fluxes. While numerical models should overcome deficiencies associated with some of the intrinsic assumptions of the two field-methods, the regional-scale calibration is subject to high uncertainties in the simulated heads near the river, resulting in uncertainty of SW-GW exchange fluxes. In particular, we show that loosely quantified river abstractions and irrigation patterns directly impact the simulated SW-GW fluxes. In gaining reaches, additional river chemistry data improved model calibration and SW-GW flux estimates. While numerical models are crucial for water management, their reliability to estimate SW-GW fluxes can be limited by their complexity and lacking data availability. Therefore, we recommend comparing numerical model results with easily implemented field-based methods.
\end{abstract}

Plain Language Summary Water circulation between surface water and groundwater in watersheds significantly impacts water management, water quality and water availability for aquatic ecosystems. At the regional scale, surface water-groundwater (SW-GW) interactions are the result of a number of interaction processes. Despite the growing demand for integrated water studies, the best approach for investigating SW-GW interactions at large scales remains unclear. We have compared directions and magnitudes of SW-GW flows estimated from commonly applied local field-studies and from the implementation of a regional numerical model, along a $140 \mathrm{~km}$ river reach in Victoria, Australia. The study highlights the advantages and limitations of each method and suggests the need for a precautionary approach in the use of regional numerical models for estimating SW-GW fluxes. Fieldbased methods are easy to implement and should be used for checking fluxes obtained from numerical models.

\section{Introduction}

Determining the nature, magnitude and heterogeneity of exchange fluxes between surface waters (SW) and groundwaters $(\mathrm{GW})$ is one of the contemporary challenges associated with management of water quantity, quality and stream ecology (Brunner et al., 2017; Harvey et al., 2013; Kiel \& Cardenas, 2014; Sophocleous, 2002). For water quantity management in particular, their quantification is essential to obtain accurate water balances. SW-GW exchange encompasses a large range of residence times and flow paths, each with distinct impacts on water quality and quantity. Hyporheic flows are rapid flows (residence time of hours to days) in and out of the streambed. Bank storage flows are intermediate flows (weeks to months) of river water stored in the banks at high stage and returned to the river at low stage. Long residence time 
SW-GW flows (years) occur because of the regional hydraulic gradient, with either a net infiltration of surface water to the aquifer or a net discharge of groundwater into the river.

A variety of techniques have been developed to estimate SW-GW exchange fluxes, each of them being based on different assumptions, having their own limitations and operating on different scales (Cook, 2015; Kalbus et al., 2006). Although combining multiple techniques is recommended, such studies are rare and usually limited to reach scales, that is from $10 \mathrm{~m}$ to $10 \mathrm{~km}$ (González-Pinzón et al., 2015). SW-GW interactions are rarely examined at the regional scale (Lamontagne et al., 2014), even though this is the relevant scale for integrated water management as well as social, economic and ecological impact studies (Barthel \& Banzhaf, 2016). Local scale methods are generally difficult to extrapolate to regional scales. Consequently, physically based numerical models of groundwater flow accounting for coupled SW-GW exchange flows have been promoted to investigate regional SW-GW interactions (Brunner et al., 2010; Brunner \& Simmons, 2012; D. Partington et al., 2011; Wöhling et al., 2018); see review of (Barthel \& Banzhaf, 2016). Indeed, integrated SW-GW flow models can integrate river and groundwater data, hydraulic and chemical data; jointly simulating all data-types could overcome uncertainties associated with each independent field method (Cook, 2015). While less uncertain SW-GW exchange flux estimates would be expected, most authors agree that the relevance of regional scale integrated modeling is limited by the time and computational efforts required and more importantly by data availability (Brunner et al., 2010; Fleckenstein et al., 2010; Semenova \& Beven, 2015).

The present study is a first attempt to address the existing lack of comparative analyses adapted to regional scale SW-GW investigations (Barthel \& Banzhaf, 2016). To do so, we estimated regional SW-GW exchange flows from two integrative and easily implemented field-based studies, an in-stream multitracer mass balance $\left({ }^{222} \mathrm{Rn}\right.$, Electrical Conductivity [EC], $\mathrm{Na} / \mathrm{Ca}$ and $\left.\delta^{18} \mathrm{O}\right)$ and a Darcy flux calculation based on nearstream piezometers, as well as from an integrated SW-GW regional model. This study aims to explore the applicability and relevance of the methods to (i) quantify fluxes and (ii) investigate the driving processes of their spatial and temporal variability. These questions are addressed through the assessment of a $140 \mathrm{~km}$ long reach of the Campaspe River, a tributary of the Murray River, Australia, that has been highly modified for irrigation development and faces water management challenges.

\section{Theory}

\subsection{Steady State Mass Balance}

\subsubsection{Conservative Solute Mass Balance}

The transport of a conservative solute in a stream can be expressed by the $1 \mathrm{D}$ advection-dispersion equation:

$$
\frac{\partial C_{s}}{\partial t}-D \cdot \frac{\partial^{2} C_{s}}{\partial x^{2}}+\frac{Q_{s}}{A} \cdot \frac{\partial C_{s}}{\partial x}=\frac{I_{\text {in }}}{A} \cdot C_{\text {in }}+\left(\frac{E}{d}-\frac{I_{\text {in }}}{A}\right) \cdot C_{s}
$$

where $C_{\mathrm{S}}, C_{\text {in }}$ are the tracer concentrations $(\mathrm{mg} / \mathrm{L})$ in the river and in river inflows, respectively, D is the longitudinal dispersion coefficient $\left(\mathrm{m}^{2} / \mathrm{s}\right)$, which is assumed to be constant, $\mathrm{Q}_{\mathrm{s}}$ is the river flow $\left(\mathrm{m}^{3} / \mathrm{s}\right), \mathrm{A}$ is the river cross-sectional area $\left(\mathrm{m}^{2}\right)$, equal to the mean river depth times the river width, $d$ is the mean depth $(\mathrm{m})$, $I_{\text {in }}$ is the inflow rate per stream length $\left(\mathrm{m}^{3} / \mathrm{m} / \mathrm{s}\right)$ and $\mathrm{E}$ is the evaporation rate $(\mathrm{m} / \mathrm{s})$. Inflows may include precipitation, tributary inflows, groundwater flows, bank storage flows and hyporheic flows.

Under steady state conditions, negligible stream dispersion and negligible inputs of dissolved salts by hyporheic flows, the mass balance of river flows and of a conservative tracer are simplified as:

$$
\begin{gathered}
\frac{\partial Q_{s}}{\partial x}=I_{\mathrm{GW}}-O_{\mathrm{GW}}+I_{\mathrm{TR}}-L-E \cdot W \\
Q_{s} \cdot \frac{\partial C_{s}}{\partial x}=I_{\mathrm{GW}} \cdot\left(C_{\mathrm{GW}}-C_{s}\right)+I_{\mathrm{TR}} \cdot\left(C_{\mathrm{TR}}-C_{s}\right)+E \cdot W \cdot C_{s}
\end{gathered}
$$


where $\mathrm{W}$ is the river width $(\mathrm{m})$; and $I_{\mathrm{GW}}, O_{\mathrm{GW}}, I_{\mathrm{TR}}, L$ are the groundwater inflow rate, the stream loss rate to the groundwater, the tributaries inflow rate and the loss rate through direct pumping, respectively, all expressed per unit of stream length $\left(\mathrm{m}^{3} / \mathrm{m} / \mathrm{s}\right) . C_{\mathrm{S}}, C_{\mathrm{GW}}, C_{\mathrm{TR}}$ are the tracer concentrations $(\mathrm{mg} / \mathrm{L})$ in the river, the groundwater and the tributaries, respectively. All variables are a function of $x$. If the spatial values of stream flows and pumping are measured, Equation 2 allows estimation of the net groundwater inflow $\left(I_{\mathrm{GW}}-\mathrm{O}_{\mathrm{GW}}\right)$ and Equation 3 allows estimation of groundwater inflows.

Equations 2 and 3 assume steady state, neglect stream dispersion, and do not explicitly consider hyporheic fluxes or bank storage inputs. While steady state conditions are never likely to be fully realized, implementation of these equations usually requires that stable conditions occur for the period of sampling. During periods between rainfall events, periods of relatively stable river flows often occur and steady state conditions may be a reasonable assumption for periods of a few days. Also, because of the temporal and spatial scales associated with hyporheic exchange, hyporheic flows can generally be neglected when estimating water and conservative tracer mass balances over distances of tens to hundreds of meters or more. Over longer timescales (weeks to months), however, rainfall events may cause large changes in river flows and consequent changes in groundwater chemistry adjacent to rivers through bank storage exchange. Bank storage exchanges are merged in the groundwater inflow term and the inflow concentration therefore reflects both regional groundwater and bank storage inflows.

Equation 3 can be implemented using a wide range of stable and radioactive geochemical tracers (Cook, 2013). Here, we used $\mathrm{EC}, \mathrm{Na} / \mathrm{Ca},{ }^{222} \mathrm{Rn}$ and $\delta^{18} \mathrm{O}$ because they are sensitive tracers of net groundwater inputs due to distinct compositions in SW and GW and because they are impacted in different ways by biological, physical and chemical processes. Additional terms are required for ${ }^{222} \mathrm{Rn}$ and ${ }^{18} \mathrm{O}$ to include additional processes which affect their concentrations, as described below. ${ }^{222} \mathrm{Rn}$ is produced in the subsurface by the alpha-decay of ${ }^{226} \mathrm{Ra}$ which belongs to the ${ }^{228} \mathrm{U}$-decay chain and is lost from surface water bodies by the combined effect of degassing to the atmosphere and radioactive decay (the half-life of ${ }^{222} \mathrm{Rn}$ is 3.8 days). As a result, ${ }^{222} \mathrm{Rn}$ concentrations in SW and GW generally differ by several orders of magnitude. Radon production in the hyporheic zone should not be neglected as it can provide ${ }^{222} \mathrm{Rn}$ input in the stream at a similar rate to groundwater inflows (Cook et al., 2006). $\delta^{18} \mathrm{O}$ and $\mathrm{EC}$ are sensitive to mixing and evaporation while $\mathrm{Na} / \mathrm{Ca}$ is only sensitive to mixing. All these tracers have been previously used to estimate GW inputs in rivers (Cartwright et al., 2011; Cook et al., 2006).

\subsubsection{Radon Mass Balance}

Changes in ${ }^{222} \mathrm{Rn}$ concentrations in the river with distance can be expressed by adding radioactive decay, gas exchange and hyporheic exchange terms to Equation 3:

$$
Q_{s} \cdot \frac{\partial A_{s}}{\partial x}=I_{\mathrm{GW}} \cdot\left(A_{\mathrm{GW}}-A_{s}\right)+I_{\mathrm{TR}} \cdot\left(A_{\mathrm{TR}}-A_{s}\right)+A_{s} \cdot W \cdot E-k \cdot W \cdot A_{s}-d \cdot W \cdot \lambda \cdot A_{s}+F_{\mathrm{Rn} \_\mathrm{HZ}} \cdot W
$$

where $A_{s}, A_{\mathrm{GW}}$, and $A_{\mathrm{TR}}$ are the ${ }^{222} \mathrm{Rn}$ activities $\left(\mathrm{Bq} / \mathrm{m}^{3}\right)$ in the river, the groundwater and the tributaries, respectively, $k$ is the gas transfer velocity across the water surface $(\mathrm{m} / \mathrm{s}), \lambda$ is the radioactive decay constant $(/ \mathrm{s}), d$ is the mean river depth (m) and $F_{R n_{-} H Z}$ is the flux of radon in or out of the hyporheic zone per unit of stream section $\left(\mathrm{Bq} / \mathrm{s} / \mathrm{m}^{2}\right)$.

The hyporheic flux term is complex and potentially the most difficult to estimate. Assuming the hyporheic zone to be one homogeneous layer, the flux of radon in and out of the hyporheic zone can be estimated from values of the mean thickness, the porosity, the ${ }^{222} \mathrm{Rn}$ production rate and the mean residence time (Cook et al, 2003, 2006; Lamontagne \& Cook, 2007). The ${ }^{222} \mathrm{Rn}$ production rate is commonly estimated from activities measured in groundwater or from sediment incubation experiments, and the mean residence time is often derived from streambed radon profiles (Bourke et al., 2014). The net flux of ${ }^{222} \mathrm{Rn}$ from the hyporheic zone can also be estimated from vertical concentration profiles in streambeds as the deficit of streambed water ${ }^{222} \mathrm{Rn}$ relative to ${ }^{222} \mathrm{Rn}$ concentrations at secular equilibrium (Cook et al., 2018; Martin et al., 2007), expressed by: 


$$
F_{\mathrm{Rn} \_\mathrm{HZ}}=\theta \cdot \lambda \int_{0}^{z \max }\left(A_{\mathrm{eq}}-A(z)\right) \mathrm{d} z
$$

where $F$ is the flux of ${ }^{222} \mathrm{Rn}$ from the hyporheic zone per unit of stream length $\left(\mathrm{Bq} / \mathrm{s} / \mathrm{m}^{2}\right), \theta$ is the averaged sediment porosity, $A_{\text {eq }}$ is the equilibrium activity in the sediment $\left(\mathrm{Bq} / \mathrm{m}^{3}\right), A(\mathrm{z})$ is the ${ }^{222} \mathrm{Rn}$ activity at depth $\mathrm{z}$ in the hyporheic zone $\left(\mathrm{Bq} / \mathrm{m}^{3}\right)$. This is not to imply that hyporheic exchange is a vertical 1D process, but rather that the radon deficit can be estimated from 1D profiles and that this deficit is largely due to hyporheic exchange. Although Equation 5 neglects the possible effect of SW-GW exchange on the vertical radon profiles, previous studies have shown that hyporheic exchange usually exceeds SW-GW exchange by an order-of-magnitude (Cranswick \& Cook, 2015) and so this omission is unlikely to be significant.

\subsubsection{Water Stable Isotope Mass Balance}

Changes in the isotopic composition of the water molecule with distance can be expressed by

$$
Q_{s} \cdot \frac{\partial \delta_{s}}{\partial x}=I_{\mathrm{GW}} \cdot\left(\delta_{\mathrm{GW}}-\delta_{s}\right)+I_{\mathrm{TR}} \cdot\left(\delta_{\mathrm{TR}}-\delta_{s}\right)-E \cdot W \cdot\left(\delta_{E}-\delta_{s}\right)
$$

where $\delta_{S}, \delta_{\mathrm{GW}}, \delta_{\mathrm{TR}}$, and $\delta_{\mathrm{E}}$, are the isotope ratios (\%) in the river, the groundwater, the tributaries and the evaporation flux, respectively.

The isotopic composition of the evaporative flux, $\delta_{E}$, is difficult to measure directly but is commonly calculated using the Craig-Gordon turbulent diffusion model (Craig \& Gordon, 1965) modified by (Gibson \& Edwards, 2002):

$$
\delta_{E}=\frac{\alpha \delta_{S}-h \delta_{A}-\varepsilon}{1-h+10^{-3} \varepsilon_{k}}
$$

where $a$ is the equilibrium liquid-vapor isotope fractionation, $h$ is the relative humidity, $\delta_{A}$ is the isotopic composition of air ambient moisture, $\varepsilon=\varepsilon^{*}+\varepsilon_{k}$ is the total isotopic separation factor comprising equilibrium $\left(\varepsilon^{*}\right)$ and kinetic contributions $\left(\varepsilon_{\mathrm{k}}\right)$ in units of parts per mil.

\subsection{Darcy Flux}

Assessing the surface water-groundwater connectivity and distinguishing between gaining-connected, losing-connected and losing-disconnected conditions is crucial for SW-GW exchange flux quantification (Brunner \& Cook, 2009; Brunner et al., 2011; Lamontagne et al., 2014).

For a homogeneous symmetric aquifer intersecting a river, assuming that the entire groundwater flow normal to the river is captured by or released from the river, the horizontal SW-GW flux is given by Darcy's law (Darcy, 1856):

$$
q_{\mathrm{GW} \rightarrow \mathrm{SW}}=-2 K_{B, H} e \frac{\partial h}{\partial x}
$$

where $q$ is the SW-GW flux per unit of stream length $\left(\mathrm{m}^{3} / \mathrm{s} / \mathrm{m}\right)$, positive under stream gaining conditions and negative under stream losing conditions, $K_{B, H}$ is the average horizontal hydraulic conductivity $(\mathrm{m} / \mathrm{s}), e$ $(\mathrm{m})$ is the thickness of the aquifer, and $\partial h / \partial x$ is the hydraulic gradient between the stream and the aquifer estimated from the head difference in groundwater and the stream divided by the distance of the piezometer to the river. The factor 2 accounts for the two sides of the river connected to the aquifer, following the assumption of a symmetric aquifer intersecting a river.

When a river is incised into a low $\mathrm{K}$ layer or where a low $\mathrm{K}$ clogging layer underlies the river, then flows from and to the river will be controlled by the hydraulic conductivity of this layer, and most of the head difference between the river and a piezometer screened in the aquifer underlying the low $\mathrm{K}$ layer will occur between the river and the aquifer immediately underneath the river. In this case, the vertical flow rate to the river is given by: 


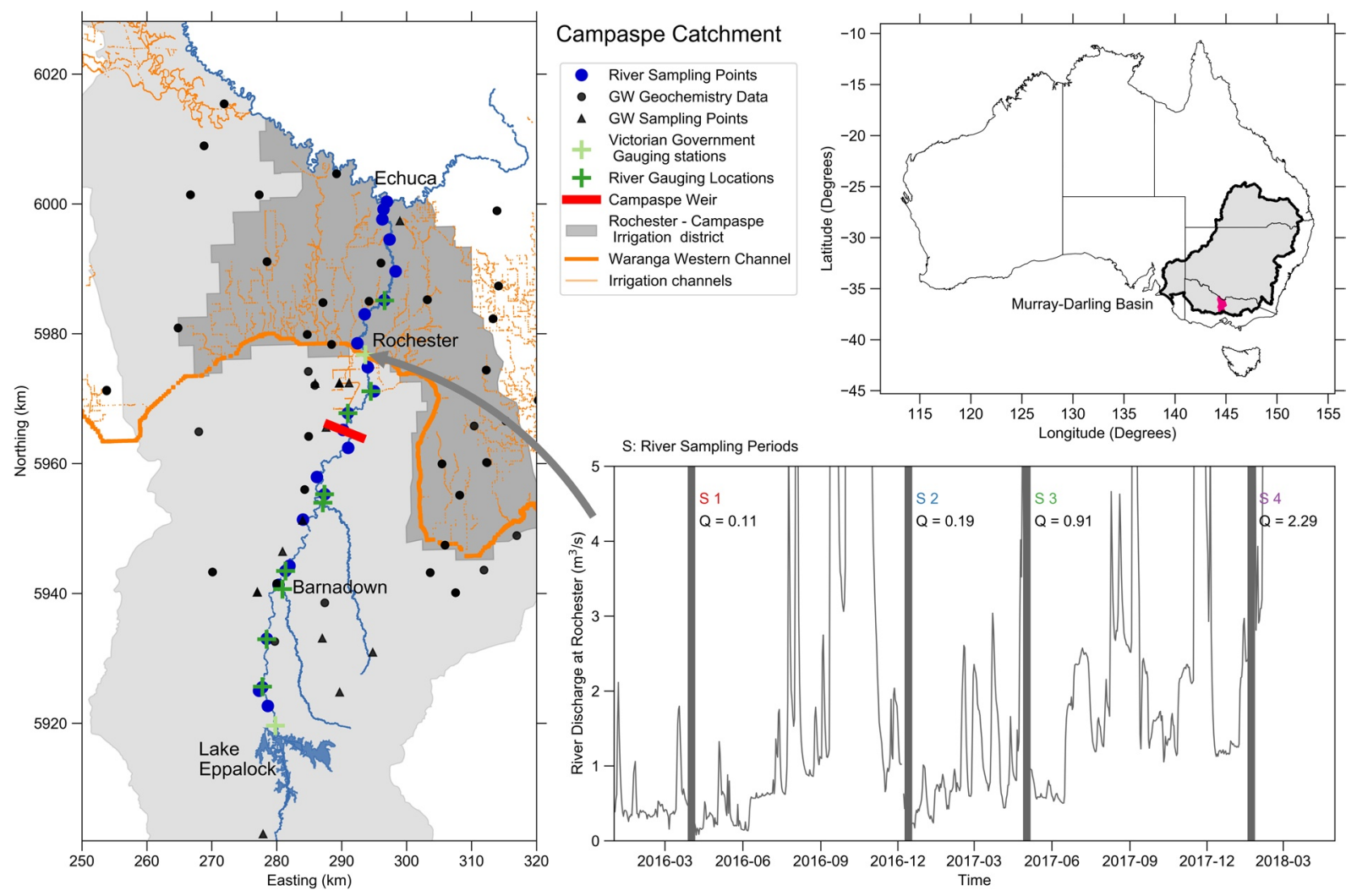

Figure 1. Map of the Campaspe Catchment, subcatchment of the Murray-Darling Basin in Australia, main towns (black italic), main dams (Lake Eppalock and Campaspe Weir), the Western Waranga Channel (WWC) and the Campaspe Siphon (where the WWC meets the Campaspe river). The studied river reach extends along $140 \mathrm{~km}$ from Lake Eppalock to the confluence with the Murray River. Blue points show the locations of the river samples. The lower right plot displays the Campaspe discharge at Rochester and the four periods of river sampling.

$$
q_{\mathrm{GW} \rightarrow \mathrm{SW}}=-K_{B, V} W \frac{\partial h}{\partial z}
$$

where $q$ is the SW-GW flux per unit of stream length $\left(\mathrm{m}^{3} / \mathrm{s} / \mathrm{m}\right), K_{B, V}$ is the average vertical hydraulic conductivity $(\mathrm{m} / \mathrm{s}), \mathrm{W}(\mathrm{m})$ is the width of the river and $\partial h / \partial z$ is the vertical hydraulic gradient between the stream and the aquifer.

In Equation 8, the relevant distance used to calculate the hydraulic gradient between the stream and the aquifer is a trade-off: as the distance from the stream increases, the hydraulic gradient captures more of the spatial and temporal heterogeneities of the stream-aquifer interactions (Noorduijn et al., 2014; Parsons et al., 2008), but it can also be affected by other factors such as pumping or evapotranspiration. For the same reason, the use of piezometers close to the river is also preferred when Equation 9 is used.

\section{Site Description: Campaspe Catchment}

The Murray-Darling Basin contains Australia's longest river system and its catchment covers an area of about one million square kilometers in the southeast of Australia (Figure 1). In 2004-2006, water use in the Murray-Darling Basin (MDB) accounted for approximately half of Australia's total water consumption, more than half of which is for agriculture (ABS, 2008). The MDB contains 65\% of Australia's irrigated land. A subcatchment of the MDB, the Campaspe catchment has been the focus of a number of recent hydrogeological studies to address concerns raised during the millennial drought (2000-2010) on increasing pressure on water resources (Xie et al., 2018). The Campaspe catchment covers $0.4 \%$ of the MDB area and provides $0.9 \%$ of its water. Typical of rivers in the south of the MDB, the Campaspe River originates from 
hilly terrains of the Great Dividing Range (annual rainfall $\sim 1,000 \mathrm{~mm}$ ), then flows north toward the riverine plains of northern Victoria (annual rainfall $\sim 400 \mathrm{~mm}$ ), before it meets the River Murray at Echuca. This study focuses on the Lower Campaspe, the $140 \mathrm{~km}$-long reach between Lake Eppalock and the River Murray (Figure 1). Groundwater occurs in a layered sedimentary aquifer-aquitard system in the northern part of the catchment and in fractured rock aquifers in the central and southern parts of the catchment. The main alluvial aquifers (from deepest to shallowest) are the Deep Lead (including the Calivil Formation and Renmark Group), the Shepparton Formation and the Coonambidgal Formation. The Campaspe Deep Lead is a laterally continuous coarse sand and gravel unit. It is the main aquifer and receives significant vertical leakage from the upper units. The Shepparton Formation comprises floodplain clays with sand lenses and therefore acts both as an aquifer and an aquitard. The proportion of sand generally decreases toward the north, where the Shepparton Formation acts as an aquitard separating the Deep Lead from the surface units. The Coonambidgal Formation consists of Quaternary fluvial sediments deposited in an eroded trench about $1 \mathrm{~km}$ wide and $15 \mathrm{~m}$ deep around the Campaspe River, and is in good hydraulic connection with the river.

Water in the catchment is highly regulated to meet water needs, mainly by the operation of Lake Eppalock, the Campaspe Weir and the Campaspe Siphon, but the volumes of water that are pumped out of the river are largely unknown. The construction of Lake Eppalock (304 GL) in 1963, the encasement in concrete of the Campaspe Weir (3 GL) in the 1950s and the diversion of water from the Goulburn catchment (east of the Campaspe catchment) through the Waranga Western Channel (WWC), allowed the development of a vast irrigation area in the northern plains, the Rochester-Campaspe Irrigation District (Figure 1). The WWC crosses the Campaspe River at the Campaspe Siphon (Figure 1) and this structure allows water to be released from the WWC to the river or pumped from the river to the channel. Water regulation reversed the natural flow pattern of the Campaspe River downstream of Lake Eppalock so that now higher flows occur during the dry season (November-January) while lower flows occur during the wet season (June-September). Annual river flows decrease from about $5 \mathrm{~m}^{3} / \mathrm{s}$ at Barnadown to about $0.7 \mathrm{~m}^{3} / \mathrm{s}$ at Echuca. Large-scale irrigation as well as river regulation (dams and channels) significantly increased recharge of the aquifers in the northern plains. As a result, the natural state of a losing stream between Lake Eppalock and Echuca have changed into weak gaining conditions between the Campaspe Weir and Echuca within the last 30 years (Wade, 2011). SW-GW exchanges along this reach are complex because of the spatial heterogeneity of the alluvial units and because both natural and anthropogenic factors control the water balance in the catchment. In particular, water regulation has a significant impact on river flux, but the volumes pumped out of the river at the weir, at the WWC and along the river are largely unmonitored.

\section{Methods}

\subsection{Data Collection}

The Campaspe River was studied over 2 years and field campaigns were conducted in autumn and summer of each year: in March-April 2016 (autumn), December 2016 (summer), May 2017 (autumn), and January 2018 (summer). Sampling campaigns were conducted at least 3 weeks after rainfall to allow neglecting rainfall and runoff in the mass balance, apart from the sampling period in May 2017 that occurred at the end of a large flood event. During each field campaign, river gauging was carried out at seven stations on the Campaspe and its tributaries, wherever the river level and riverbed geometry permitted, using a Hach FH550 flowmeter (Figure S1). The tributaries only flowed in April-May 2017. Between 18 and 23 river water samples were collected along the $140 \mathrm{~km}$ reach (an average of one sample every $7 \mathrm{~km}$; Figure 1). Exact locations were measured with a GPS and then converted into river distance expressed downstream of Lake Eppalock. From one sampling period to another, samples were added at locations at which preliminary results showed sharp changes in the river chemistry. EC, $\mathrm{pH}$ and temperature were measured in the field using a WTW 3420 Meter (Figure S1). Alkalinity was determined on site using a Hach digital titrator. River samples were analyzed for major ions, stable isotopes and ${ }^{222} \mathrm{Rn}$ (Figure S1). Cations were measured by ICP- OES (Agilent 5100) on filtered $(0.45 \mu \mathrm{m})$ and acidified $(\mathrm{pH}<2)$ samples. Anions were measured by ion chromatography (Dionex ICS-2500) on filtered $(0.45 \mu \mathrm{m})$ and unacidified samples. Analyses of stable isotopic ratios (expressed as $\delta^{18} \mathrm{O}$ and $\delta^{2} \mathrm{H}$ ) were undertaken on a Picarro L2130-i. Uncertainties are $0.05 \%$ for $\delta^{18} \mathrm{O}$ and $0.3 \%$ for $\delta^{2} \mathrm{H}$ and the difference between repeated measurements is below $5 \%$. Surface water samples for radon determination were collected following the PET-Method (Leaney \& Herczeg, 2006). In brief, water was 
collected in a 1,250 mL plastic bottle from which $50 \mathrm{~mL}$ were removed and $20 \mathrm{~mL}$ of scintillant were added. The bottle was then shaken for 5 min to equilibrate radon between the air-water-scintillant phases. After allowing the bottle to settle for a few minutes, the scintillant was extracted and placed in a counting vial.

In January 2019, hyporheic porewater was sampled using a $1.7 \mathrm{~m}$ long drive-point piezometer (12 $\mathrm{mm}$ OD, $9 \mathrm{~mm}$ ID), with a filtered screen over a $2 \mathrm{~cm}$ section at the tip, which was pushed into the stream sediments by hand, or using a small hammer. Porewater was sampled using a hand-operated peristaltic pump. After purging the mini-piezometer, $14 \mathrm{~mL}$ of hyporheic water was collected using a syringe with a needle submerged inside the open-end of the pump tube to minimize degassing, and injected into preweighted counting vials containing $7 \mathrm{~mL}$ of scintillant, following the radon Direct-Method (Leaney \& Herczeg, 2006). Radon streambed depth-profiles were sampled at 10 different locations. Each profile consisted of porewater samples every $15 \mathrm{~cm}$ to as deep as possible (maximum depth $=1 \mathrm{~m}$ ) (Figure S2). Surface sediments $(0-10 \mathrm{~cm})$ in the streambed were collected by hand at eight locations (Figure 1), then saturated with deionized water and sealed in $500 \mathrm{~mL}$ glass containers in order to determine the ${ }^{222} \mathrm{Rn}$ equilibrium activity. Two split replicates were done when the amount of sediments permitted. After a month, which corresponds to the time to reach radioactive equilibrium between sediment production and radioactive decay, we sampled porewater in each glass jar following the Direct-Method (Figure S2).

In December 2016, groundwater samples were collected from 12 wells after purging three times their volumes. EC, pH, temperature, alkalinity, major ions, and stable isotopes were analyzed, following the same procedure as described for the river samples. Groundwater samples for radon determination were collected following the Direct-Method (Leaney \& Herczeg, 2006).

Radon concentrations of river, hyporheic and groundwater samples were measured by Liquid Scintillation Counting, using the pulse shape analysis program to discriminate alpha and beta decay (Herczeg et al., 1994). Radon concentrations are expressed in Becquerel of radioactivity per liter of water (Bq/L) and corrections were made to account for radioactive decay between the time of sampling and the time of counting.

\subsection{Implementation of Tracer Mass Balance}

Steady state mass balance equations were solved numerically for every sampling period for ${ }^{222} \mathrm{Rn}, \mathrm{EC}, \mathrm{Na}$ and $\mathrm{Ca}$ ion concentrations (expressed in terms of the $\mathrm{Na} / \mathrm{Ca}$ ratio) and $\delta^{18} \mathrm{O}$ (Figure S1), using an explicit finite difference method and a discretization length of $1 / 500$ of the total river reach length. The upper boundary conditions are the concentrations measured in Lake Eppalock in the upstream part of the river. Pumping rates at the Campaspe Weir were estimated from averaged monthly data on surface water extractions (provided by Goulburn Murray Water). For December 2016 and May 2017, it was not necessary to include any additional pumping to provide an acceptable fit to streamflows. However, in April 2016 and January 2018, additional pumping at the Campaspe Weir was included to reproduce better the observed stream flow changes (Table S1).

As no significant trends in river width and depth were observed with distance, we simplified the conceptualization of the river by considering constant values of depth and width along the entire river for each sampling period (Table S1, Figure S1). Climatic data (evaporation, precipitation, and relative humidity) were obtained from weather stations at Lake Eppalock, Kyneton, Rochester, Elmore, and Echuca. For each sampling period, evaporation rates were calculated as the average of the measured rates of the five stations (Table S1). Negligible rainfall and surface runoff were assumed and tributaries flows were measured. The major ion composition of rain was from (Crosbie, 2012). Isotopic compositions were for Melbourne rainfall (IAEA station WMO 9486800) (Table S1). Equilibrium fractionation, which varies with temperature, was calculated from (Majoube, 1971). Kinetic separation factors were assumed to be $14.2 \%$ and $12.5 \%$ for oxygen-18 and deuterium, respectively (Horita et al., 2008). Atmospheric moisture is assumed to be at equilibrium with regional precipitation.

Although obtaining a representative end-member is essential for calculating groundwater fluxes using tracer mass balances (Atkinson et al., 2015), the heterogeneities in the groundwater compositions (Cartwright, 2010) over a $140 \mathrm{~km}$ long reach require numerous and well distributed groundwater samples. Here, we assumed a groundwater end-member invariant along the river reach but potentially different between 
sampling periods. Groundwater concentrations are thus set up as unknowns in Equations 23456 . For each sampling period, unknown parameters therefore included the gas transfer velocity (GTV), an averaged groundwater composition $\left({ }^{222} \mathrm{Rn}\right.$ activity, EC, Na concentration, $\mathrm{Na} / \mathrm{Ca}$ ratio, $\left.\delta^{18} \mathrm{O}\right)$ and SW-GW fluxes. SW-GW fluxes were estimated for as many subreaches as the number of observation points in the river. Parameter estimation was performed using the DREAM algorithm (Vrugt \& Braak, 2011) implemented with the spotpy package in Python (Houska et al., 2015). The likelihood function chosen was the RMSE between simulations and observations, each of them normalized by the amplitude of observed data to allow comparisons of the different data types. The posterior probability density distribution for each parameter was calculated from the last $40 \%$ of the samples generated with the DREAM algorithm.

\subsection{Derivation of SW-GW Fluxes from Darcy Flux Calculation}

Groundwater hydraulic head data and river flows were extracted from the Victorian Government database. Piezometers were selected according to the following criteria: (1) located less than $1.5 \mathrm{~km}$ from the river, (2) hydrogeological unit of the screened interval clearly identified, and (3) at least 10 years of available data. Streambed elevation was surveyed in January 2018 using an integrated Global Navigation Satellite System Real Time Kinematic System (Trimble 10), connected to a Virtual Reference Station Network. We collected 89 measurements of the streambed position, with an average horizontal precision of $4 \mathrm{~cm}$ and an average vertical precision of $6 \mathrm{~cm}$. The transmissivity of the Shepparton Formation ranges between $9 \times 10^{-4}$ and $3 \times 10^{-3} \mathrm{~m}^{2} / \mathrm{s}$ and the horizontal hydraulic conductivity ranges between $2 \times 10^{-4}$ and $1 \times 10^{-3} \mathrm{~m} / \mathrm{s}$ (Wade, 2011). The vertical hydraulic conductivity of the Shepparton Formation decreases northward from $1 \times 10^{-7} \mathrm{~m} / \mathrm{s}$ to $3.5 \times 10^{-10} \mathrm{~m} / \mathrm{s}$ (Arad \& Evans, 1987; Wade, 2011). We linearly interpolated the thickness and vertical hydraulic conductivity of the Shepparton Formation from $10 \mathrm{~m}$ and $10^{-7} \mathrm{~m} / \mathrm{s}$ at Lake Eppalock to $50 \mathrm{~m}$ and $3.5 \times 10^{-10} \mathrm{~m} / \mathrm{s}$ at the Murray River, and applied an uncertainty factor of 5 to this value, which is similar to that for the horizontal hydraulic conductivity

In the southern part of the catchment, hydraulic heads in the Shepparton Formation are below the river heads and chemical data indicate leakage from the river to the Deep Lead. In the northern part of the catchment, hydraulic heads of the Shepparton Formation are above river levels, indicating flow from the Shepparton groundwater into the river. This change is due to the increasing clay proportion and total thickness of the Shepparton Formation toward the north and associated decrease in the vertical permeability. SW-GW fluxes have therefore been calculated according to Equation 8 using head gradients in the Shepparton formation directly in contact with the river. When the river is losing water, we also calculated a vertical SW-GW flux using Equation 9 with head gradients measured in the Deep Leads and using the width of the floodplain (1,000 $\mathrm{m}$ in total width). The width of the floodplain was used because the low permeability layer occurs between the permeable floodplain sediments (which are in direct contact with the river) and the underlying aquifer. The vertical flux therefore occurs across the entire width of the floodplain.

Because of the small number of groundwater-head measurements in the Campaspe catchment and their unequal distribution in space and time, we cannot accurately calculate temporal snapshots of SW-GW exchange fluxes. Therefore, for each piezometer, we calculated the distribution of SW-GW exchange fluxes using all head data and assuming a uniform distribution of hydraulic conductivity of the respective hydrogeological unit. By doing so, we accounted for variability of head measurements and hydrogeological parameters.

\subsection{Numerical Modeling}

The regional scale surface water-groundwater flow model utilized in this study is described in detail in (Partington et al., 2020) and only summarized here. The flow model was built with MODFLOW-NWT (version 1.1.2) (Niswonger et al., 2011). It was run at a monthly time step on a $1 \mathrm{~km} \times 1 \mathrm{~km}$ horizontal grid and consisted of seven layers of varying thickness corresponding to the thickness of the hydrogeological units (Figure S4). The model was forced by recharge, groundwater pumping, river inflow from the Lake Eppalock dam, drains and a general head boundary at the northern end of the model domain beneath the Murray River to allow groundwater outflow (Figure S4). Recharge in 16 recharge zones were determined from a water balance approach based on mean annual precipitation and soil type (Xie et al., 2018). Streamflow routing 


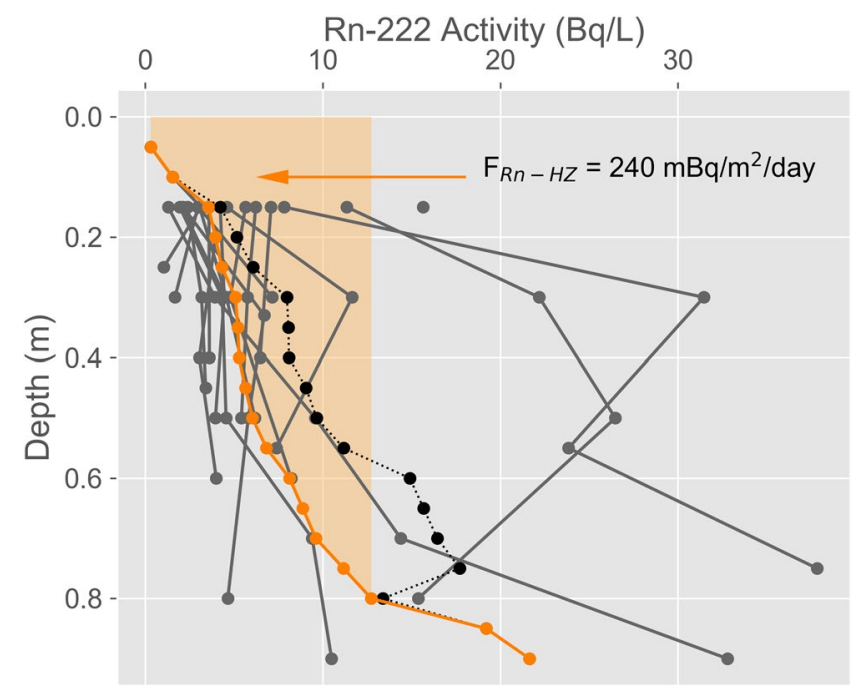

Figure 2. Averaged streambed radon profiles. The black dotted line is the average of all profiles, and the orange line is the average without the two most concentrated outlier profiles. The orange shaded zone is the ${ }^{222} \mathrm{Rn}$ deficit attributed to diffusion. was used to model the Campaspe River flow including inflow from Lake Eppalock, as well as diversions in and out of the river along its course to the Murray River. The SW-GW exchange calculated within the flow model is based on the simulated stream stage and underlying aquifer hydraulic head, the specified streambed hydraulic conductivity and thickness. Simulation of in-stream transport of EC and ${ }^{222} \mathrm{Rn}$ was done similarly to the model described in Section 3.2, using simulated in-stream flows and SW-GW exchange flows that were output from the flow model. The prior distribution of hydraulic conductivity was determined from available pumping test results, and the prior normal distribution for other model parameters (including specific yield, porosity, riverbed conductance and hyporheic zone parameters) were determined from literature values. Using PEST (Doherty, 2016) with regularization, the model parameters were log-transformed and calibrated to monthly average hydraulic heads at observation piezometers located over the entire catchment $(n=1886)$, river level and discharge data $(n=67)$, radon $(n=59)$ and EC measurements $(n=91)$ in the river, and ${ }^{14} \mathrm{C}$ measurements in groundwater $(n=11)$.

\section{Results}

\subsection{Estimates of SW-GW Fluxes from Streamflow and MultiTracer Mass Balances}

\subsubsection{Streamflows and River Chemistry}

Measured values of streamflow, EC, chloride, radon, $\mathrm{Na} / \mathrm{Ca}$ and $\delta^{18} \mathrm{O}$ are depicted in Figure $\mathrm{S} 1$ for the four sampling periods. Geochemical profiles of the river show similar patterns between sampling periods with an overall increase in $\mathrm{EC}, \mathrm{Cl}, \mathrm{Na} / \mathrm{Ca}$ and $\delta^{18} \mathrm{O}$ along the river. Compositions at Lake Eppalock $(\mathrm{km} 0)$ differed between sampling periods and higher $\mathrm{EC}, \mathrm{Cl}$, and $\delta^{18} \mathrm{O}$ were measured during summer months (Figure S1), reflecting more evaporated waters. In contrast, streamflows did not show a natural seasonality (Figure S1) and the highest streamflows were measured in summer as a result of sustained discharges from Lake Eppalock. Stream radon profiles show a large decrease in radon activity in the first $5 \mathrm{~km}$, then fairly stable activities up to the Campaspe Weir and higher activities downstream, suggesting higher groundwater inputs in the downstream part of the river.

\subsubsection{Hyporheic Zone Radon Flux from Streambed Radon Profiles}

Equilibrium activities from incubation of the riverbed surface sediments ranged from 1.4 to $15.9 \mathrm{~Bq} / \mathrm{L}$ with an average of $4.5 \mathrm{~Bq} / \mathrm{L}$ and a median of $1.95 \mathrm{~Bq} / \mathrm{L}$. Streambed radon activities ranged from 0.3 to $37.8 \mathrm{~Bq} / \mathrm{L}$ with an average of 7.9 Bq/L and a median of $4.6 \mathrm{~Bq} / \mathrm{L}$ (Figure 2). Radon activities were much higher in the $\mathrm{HZ}$ than in the river $(<0.5 \mathrm{~Bq} / \mathrm{L})$, suggesting a water residence time at the bottom of the hyporheic zone of several days (Cranswick et al., 2014). Most profiles showed an increase in ${ }^{222} \mathrm{Rn}$ concentrations with depth (Figure 2). Two profiles had higher concentrations and one of these had concentrations that decreased with depth. This could be related to upwelling water together with locally high production rates. The expected heterogeneity of ${ }^{222} \mathrm{Rn}$ profiles in the streambed likely results from spatial heterogeneity in flows and production rates.

Most profiles reached a maximum depth of $0.8 \mathrm{~m}$ with an averaged ${ }^{222} \mathrm{Rn}$ activity of $12.5 \mathrm{~Bq} / \mathrm{L}$, a value within the lower range of ${ }^{222} \mathrm{Rn}$ activities measured in the surrounding groundwaters $(20 \%$ of samples were below $13.5 \mathrm{~Bq} / \mathrm{L}$ ). The integration of the averaged ${ }^{222} \mathrm{Rn}$ streambed profile deficit, with an equilibrium activity of $12.5 \mathrm{~Bq} / \mathrm{L}$ and an average porosity of 0.3 , yielded a radon flux of $240 \mathrm{mBq} / \mathrm{m}^{2} /$ day (Equation 5, Figure 2). No significant trend in hyporheic profile with distance along the river is apparent, and so this value was assumed to be representative of the inflow of radon from the hyporheic zone to the stream per unit of stream length over the entire river reach. 

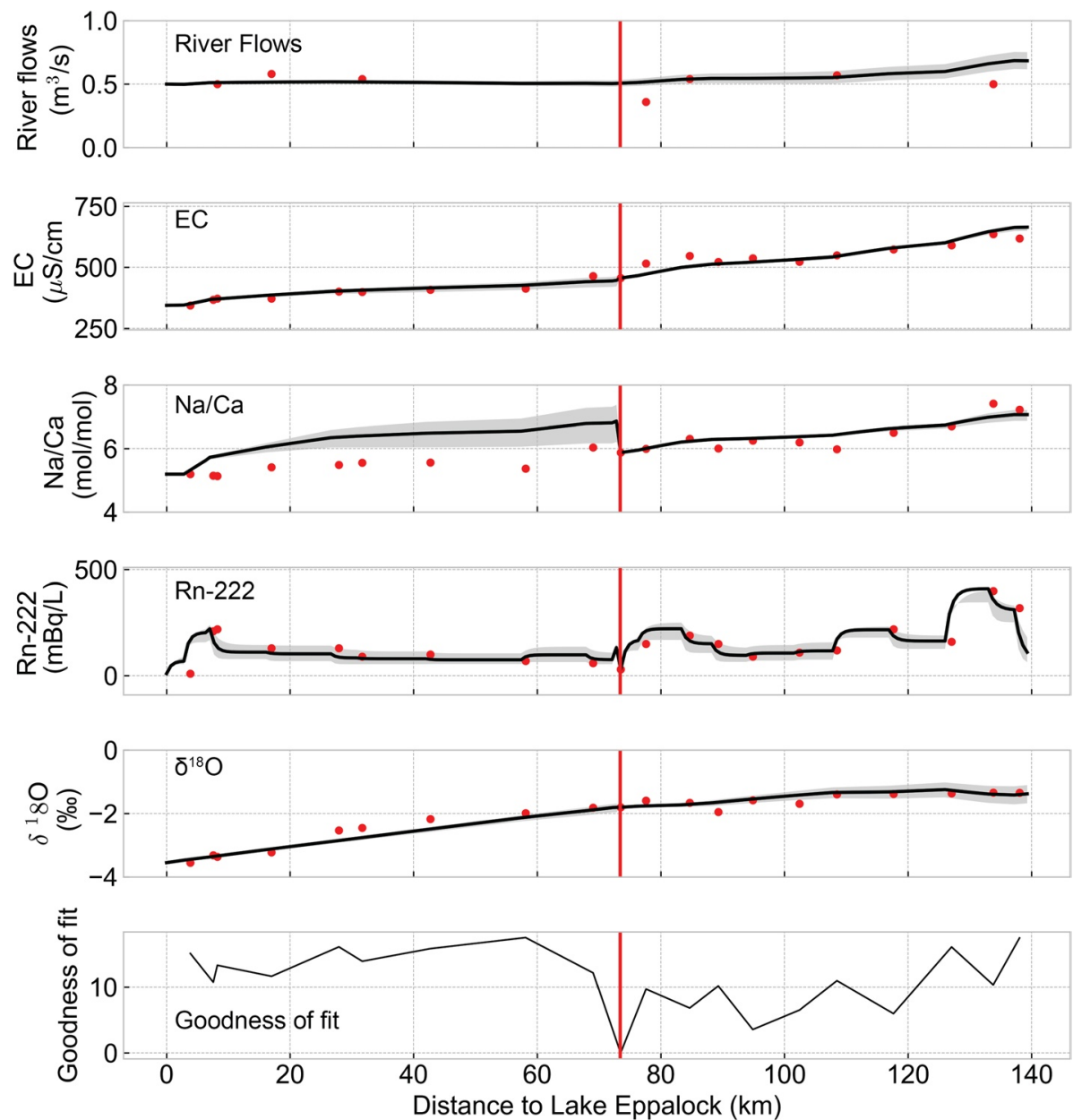

Figure 3. Results of the calibration of stream tracer mass balances in December 2016. Black lines are the mean simulations; gray areas are the ranges of simulations for the ranges of accepted parameters. Red dots are observations used to calibrate the tracer mass balance. The vertical red line shows the Campaspe weir location. Better fits are indicated by lower likelihood function values.

\subsubsection{Simulation of Stream-Tracer Profiles}

Simulations of streamflows show poor fits with observations, particularly in January 2018 where the decreases in river flows are not well simulated. As water losses do not alter river concentrations, the longitudinal tracer mass balance alone cannot differentiate between river abstraction and groundwater outflows unless it is combined with a water balance based on accurate river flow data. Therefore, unmonitored water use through dams or canals or unmetered river abstraction prevent the use of the longitudinal chemical mass balance to determine discharge to the aquifer. Groundwater inflow rates are insensitive to pumping rates but in error proportional to the error in streamflow, their estimation thus rely on a reasonable fit to streamflow. The inclusion of additional pumping partly corrects the lack of closure of the river flux mass balance, allowing the simulation of correct volumes and an accurate estimation of SW-GW exchange fluxes in gaining reaches.

Simulations of EC, ${ }^{222} \mathrm{Rn}, \mathrm{Na} / \mathrm{Ca}$ ratio and $\delta^{18} \mathrm{O}$ show good fits to observations during the four field campaigns (Figure 3/Figures S5-S8). However, some differences between simulations and observations remain higher than the measurement uncertainty and the goodness of fit was not improved by increasing the acceptance of parameters in the Markov Chain Monte Carlo method (MCMC). This shows either processes that are missing in the conceptualization of the mass balance model or errors in the forcing data that drive the model (climatic data and river withdrawal data). In May 2017, the high EC, high $\mathrm{Na} / \mathrm{Ca}$ ratio, low $\delta^{18} \mathrm{O}$ and low ${ }^{222} \mathrm{Rn}$ measured in the upstream part of the Campaspe in May 2017 cannot be simulated by the 
steady-state mass balance model. This sampling period occurred at the end of a large flood event (Figure 1) and data were likely sampled on the subsiding flood wave (Xie et al., 2016) as EC was much lower just a few days later (Figure S1). In April 2016, concentrations in the river decreased considerably in the last $10 \mathrm{~km}$ reach, coincident with a decrease in ${ }^{222} \mathrm{Rn}$ and an increase in river flows (Figure S1), indicating an input of radon-free freshwater likely related to an input of surface water from the WWC at the Campaspe siphon. In both cases, the major discrepancies between observations and simulations reveal limitations in the developed steady-state conceptual mass balance model, which neither accounts for transient conditions nor additional water inputs. The unfitted observations both in May 2017 and in April 2016 therefore were not used to calibrate the parameters of the mass balance model (Figure 4). For the other sampling times, systematic but small differences between observations and simulations likely arised from the use of a fixed composition of groundwater along the reach. Multiple groundwater end members could be implemented if more data were available to characterize this variability. Hyporheic excursions might also change the steady-state EC concentrations in the river (Swanson et al., 2015).

\subsubsection{Calibration of Stream-Tracer Mass Balance Parameters}

For each sampling period, posterior distributions of parameters were calculated from the $40 \%$ of simulations with the highest likelihood (Figure 4). Uniform prior distributions of parameters are represented by the Y-axis range of each graph and posterior distributions are represented with boxplots. Calibrated mean gas transfer velocities (GTV) ranged between 2.7 and $4.3 \mathrm{~m}$ /day (Figure 4), while the empirical relationships defined by (Negulescu \& Rojanski, 1969; O'Connor \& Dobbins, 1956) would yield values between 1.1 and $2.4 \mathrm{~m} /$ day. Calibrated GTV are directly correlated to the radon flux from the hyporheic zone (Cartwright \& Hofmann, 2016) and therefore the high GTV could be linked to a slight overestimation of the ${ }^{222} \mathrm{Rn}$ flux from the HZ. However, the occurrence of many logs and riffles in the Campaspe River leads to turbulent flows that promote degassing not accounted for in the GTV calculations (Cartwright et al., 2014).

Compositions of the groundwater end-members lie between a river signature and a regional groundwater signature (Table S2) (Cartwright, 2010; Cartwright \& Morgenstern, 2012; Cartwright et al., 2006), consistently for all tracers. Significantly different compositions are found in different time periods (Figure 4). The estimated groundwater inflow concentration represents a mix between bank storage flows, assumed to be close to a river signature, and regional groundwater flows. This mix is likely to change with the season. Assuming EC values of $4,000 \mu \mathrm{S} / \mathrm{cm}$ in the groundwater and $500 \mu \mathrm{S} / \mathrm{cm}$ in the river, we find that groundwater inflows are always dominated by bank storage flows, at 93\% in May 2017, at 78\% in December 2016 and at 70\% in January 2018 and March 2016. Similar proportions are found with Na. (McCallum et al., 2010) has previously shown that bank storage processes are likely to result in groundwater inflow to rivers that is always a mixture of groundwater and surface water. The low radon activities in autumn were below the equilibrium activity, showing groundwater inflows with a residence time of less than a month. Higher bank storage flows in autumn can be a consequence of floods (Figure 1), or irrigation releases from Lake Eppalock.

\subsubsection{GW Exchange Fluxes}

Groundwater inflows ( $\mathrm{m}^{3} / \mathrm{m} /$ day) were calculated for a number of subreaches determined by the number of river observation points (Figure 4). Groundwater inflows varied significantly between 0 and $0.2 \mathrm{~m}^{3} / \mathrm{m} /$ day, both in space and time. GW-SW fluxes show some similar features throughout the periods with hotspots of GW inflows downstream of Lake Eppalock and within the downstream irrigation area. On average, GW inflows are higher downstream of the Campaspe Weir than upstream $\left(0.07\right.$ against $0.04 \mathrm{~m}^{3} / \mathrm{m} /$ day in April 2016; 0.19 against $0.08 \mathrm{~m}^{3} / \mathrm{m} /$ day in December 2016; 0.22 against $0.09 \mathrm{~m}^{3} / \mathrm{m} /$ day in May 2017; and 0.17 against $0.09 \mathrm{~m}^{3} / \mathrm{m} /$ day in January 2018), following previous findings (Wade, 2011). Cumulative groundwater inflows, in $\mathrm{m}^{3}$ /s, were 0.07 in April 2016, 0.18 in December 2016, 0.17 in May 2017, and 0.16 in January 2018 , which respectively accounted for $12 \%, 28 \%, 13 \%$, and $6 \%$ of stream flows at Echuca. GW inflows as a fraction of river flow were thus higher in summer (December) and they were also more variable (Figure 4).

\subsubsection{Hydrochemical and Isotopic Trends Along the River Reach}

The river discharge differences between Lake Eppalock and the Murray River $\left(\mathrm{m}^{3} / \mathrm{s}\right)$ are calculated for each time period, together with the river abstraction $\left(\mathrm{m}^{3} / \mathrm{s}\right)$, evaporation $\left(\mathrm{m}^{3} / \mathrm{s}\right)$ and groundwater inflows $\left(\mathrm{m}^{3} / \mathrm{s}\right)$ (Table 1). For comparison, the EC and isotope ratio $\left(\delta^{18} \mathrm{O}\right)$ at the end of the reach are compared to simulated values at the outlet assuming (a) no groundwater inflow (river abstraction and evaporation only), and (b) 

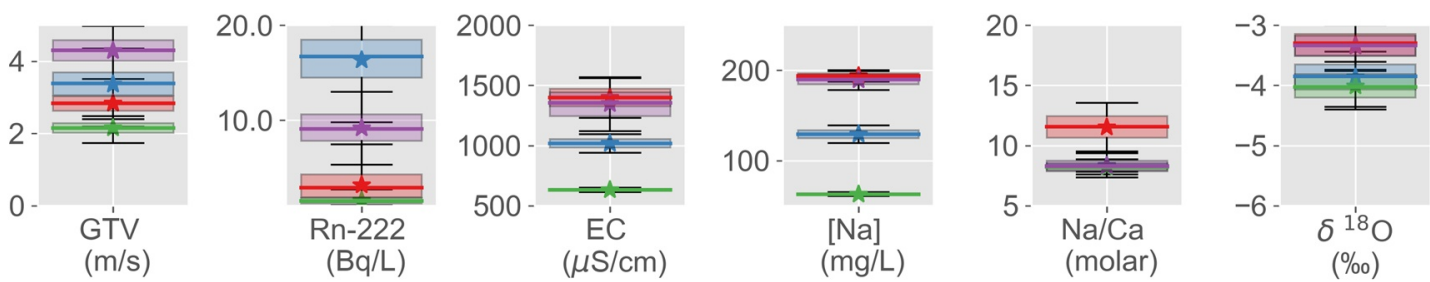

SW-GW fluxes $\left(\mathrm{m}^{3} /\right.$ day $\left./ \mathrm{m}\right)$
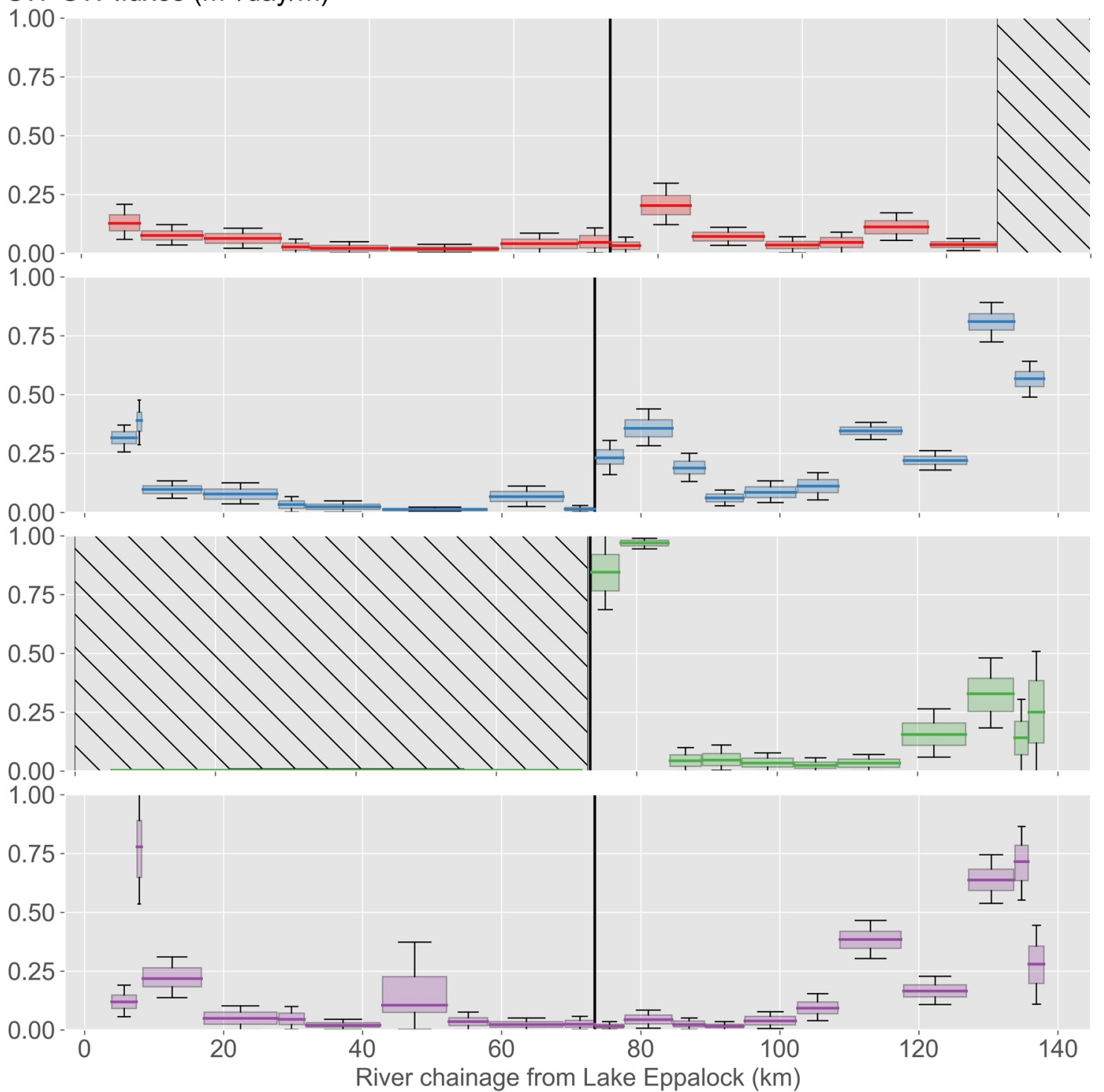

03-04 / 2016

12 / 2016

$05 / 2017$

$01 / 2018$

Figure 4. Composition of the groundwater end-member and of groundwater inputs ( $\mathrm{m}^{3} / \mathrm{m} /$ day) derived from the multitracer mass balances (a) Boxes show statistical boxplots (horizontal lines: median, boxes: interquartile ranges (IQR), whiskers: 1.5 times the IQR, black circles: outliers, and stars: mean of the distribution). Prior uniform distributions of the parameters were from left to right $[0,5],[1,20]$, [500,5000], [20,250], [5,200], [-7, -3$]$. (b) Boxes show statistical boxplots (horizontal lines: median, boxes: interquartile ranges (IQR), whiskers: 1.5 times the IQR). Box-plot widths represent the length of the River reach constrained by observation points. Striped areas show low-confidence results, where simulations do not fit observations (likelihood function>30). 
Table 1

Campaspe River Water and Chemistry Balance

\begin{tabular}{|c|c|c|c|c|c|c|c|c|}
\hline & \multicolumn{4}{|c|}{ Flow rates } & \multicolumn{4}{|c|}{$\mathrm{EC}(\mu \mathrm{S} / \mathrm{cm})$ and $\delta^{18} \mathrm{O}(\%)$ values } \\
\hline & $\Delta \mathrm{Q}\left(\mathrm{m}^{3} / \mathrm{s}\right)$ & $\begin{array}{l}\text { River abstraction } \\
\qquad\left(\mathrm{m}^{3} / \mathrm{s}\right)\end{array}$ & $\begin{array}{l}\text { E total } \\
\left(\mathrm{m}^{3} / \mathrm{s}\right)\end{array}$ & $\begin{array}{c}\Sigma \mathrm{GW} \text { inflows } \\
\left(\mathrm{m}^{3} / \mathrm{s}\right)\end{array}$ & $\begin{array}{l}\text { Initial } \\
\delta^{18} \mathrm{O} \text { EC }\end{array}$ & $\begin{array}{c}\text { Final } \\
\delta^{18} \mathrm{O} \text { EC }\end{array}$ & $\begin{array}{l}\text { Sim. }\left(E+Q_{\text {pump }}\right) \\
\delta^{18} \mathrm{O} \text { EC }\end{array}$ & $\begin{array}{c}\operatorname{Sim}\left(E+Q_{\text {pump }}+G_{\text {in }}\right) \\
\delta^{18} \mathrm{O} \text { EC }\end{array}$ \\
\hline \multirow[t]{2}{*}{ March 2016} & $0.32 \pm 0.04$ & 0.3 & 0.11 & $0.08 \pm 0.04$ & 2.7 & 4.0 & 4.9 & $4.31 \pm 0.3$ \\
\hline & & & & & 650 & 800 & 763 & $817 \pm 15$ \\
\hline \multirow[t]{2}{*}{ December 2016} & $-0.18 \pm 0.05$ & 0 & 0.09 & $0.27 \pm 0.05$ & -3.55 & -1.35 & 0.9 & $-1.38 \pm 0.30$ \\
\hline & & & & & 344 & 632 & 415 & $665 \pm 10$ \\
\hline May 2017 & $\mathrm{x}$ & $\mathrm{x}$ & $\mathrm{x}$ & $\mathrm{x}$ & $\mathrm{x}$ & $\mathrm{x}$ & $\mathrm{x}$ & $\mathrm{x}$ \\
\hline \multirow[t]{2}{*}{ January 2018} & $0.94 \pm 0.10$ & 1 & 0.16 & $0.22 \pm 0.10$ & -0.82 & -0.12 & 0.02 & $-0.03 \pm 0.1$ \\
\hline & & & & & 430 & 507 & 452 & $520 \pm 5$ \\
\hline
\end{tabular}

Notes. River discharge differences $(\Delta \mathrm{Q})$ are given and compared to the sum of input and output fluxes along the river reach: water abstraction, evaporation rates and groundwater inflows as in the tracer mass balance model. EC and $\delta 18 \mathrm{O}$ at the end of the reach are given together with simulated with river abstraction and evaporation only and with groundwater inflows. No results are given for the May 2017 campaign as steady state conditions were not fulfilled. The final observed values are taken upstream of the decrease occurring at the end of the river reach, to avoid bias due to the input of irrigation fresh water.

including groundwater inflow (river abstraction, evaporation and groundwater inflows all included). Water abstraction, although uncertain, dominates the total water budget of the river; evaporation and groundwater inflow rates are of the same order of magnitude, but significantly less than abstraction. The increase in both the hydrochemical and isotopic concentrations along the river reach is due to evaporation but inputs of more concentrated and depleted groundwater are also significant (Table 1).

\subsection{Estimates of SW-GW Fluxes from Darcy Flux Calculations}

SW-GW flows estimated from Darcy flux calculations using head gradients in the Shepparton Formation ranged between -3 and $3 \mathrm{~m}^{3} / \mathrm{m}$ /day (Figure 5). The river is losing water through the Shepparton Formation in the southern part of the catchment (negative fluxes) with average flows of $2 \mathrm{~m}^{3} / \mathrm{m} /$ day. Downstream of the Campaspe Weir, gaining conditions yielded averaged groundwater discharges from the Shepparton Formation to the river of $0.5 \mathrm{~m}^{3} / \mathrm{m}$ /day (Figure 5). The downstream gaining condition would be related to an artificially elevated water table caused by enhanced recharge associated with irrigation (Parsons et al., 2008; Wade, 2011).

The interquartile range of the SW-GW flow distribution for each reach is indicative of the temporal variability of flows at that reach due to the variability of groundwater heads. The largest interquartile ranges of SW-GW flows thus point to the most dynamic reaches. SW-GW flows were found to be most variable $60 \mathrm{~km}$ downstream of Lake Eppalock and at the most downstream part of the studied reach (Figure 5). The large and irregular irrigation in the downstream part of the catchment could explain the high temporal variability of groundwater heads near the river, and thus of SW-GW flows. Pumping near the river might explain the large range of SW-GW flows calculated $60 \mathrm{~km}$ down of Lake Eppalock. Interestingly, the most dynamic reaches shown by the Darcy approach, correlate with reaches where calibrated groundwater inflows, from the tracer mass balance model, show largest differences between sampling periods.

\subsection{Estimates of SW-GW Fluxes from Numerical Flow Modeling}

The calibration of the hydrogeological model yielded a Nash-Sutcliffe efficiency coefficient for the calibrated groundwater hydraulic heads of $0.83(n=1886)$, for streamflow of $-2.54(n=67)$, for EC -0.82 $(n=91)$, and on ${ }^{222} \mathrm{Rn}$ of $0.04(n=59)$. The poor fit of streamflow observations are attributed to a number of sources, but are partly explained by the weighting of observations in the objective function of PEST, for which GW head is dominant. The error in groundwater hydraulic head propagates through to stream flows. Unaccounted riverflow regulation also introduces error to the streamflow that prevents better fitting of the streamflow observation types. Although the longitudinal tracer mass balance could not differentiate 


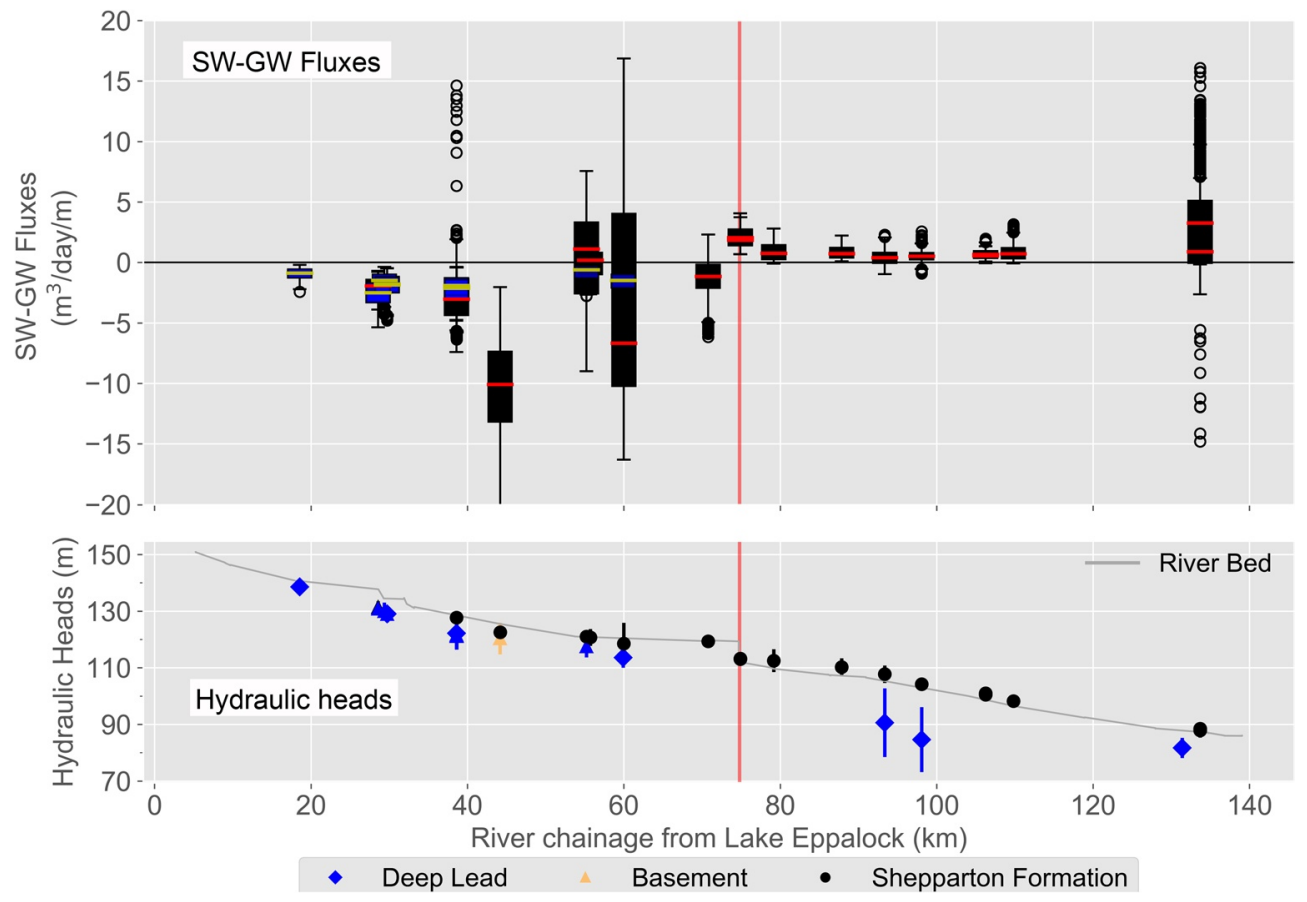

Figure 5. (Top plot) Distributions of SW-GW exchange fluxes (m3/m/day) derived from Darcy's law calculations (horizontal lines: median, boxes: interquartile ranges (IQR), whiskers: 1.5 times the IQR, black circles: outliers). In black are represented horizontal fluxes between the river and the Shepparton Formation. Positive fluxes are stream gaining conditions and negative fluxes are stream losing conditions. In blue are represented theoretical fluxes calculated from heads in the Deep Leads. (Bottom plot) Averaged heads of selected piezometers. The gray line is the streambed elevation profile derived from RTK measurements. The red vertical line shows the location of the Campaspe weir. RTK, Real Time Kinematic.

between water pumping out of the river and river discharge to the groundwater, the numerical model can simulate river discharge to the aquifer. Therefore, the overestimation of flows in the model is due to the lack of river pumping data, and not to underestimated discharge fluxes. It is not surprising that $\mathrm{EC}$ and ${ }^{222} \mathrm{Rn}$ are also not well simulated, as errors on river volumes prevent accurate mass balances in the river. Although the lack of closure of the river flux mass balance is a serious limitation to quantify fluxes in the catchment, the good fit on hydraulic heads gives confidence on SW-GW fluxes estimates albeit with the aforementioned propagation of error in the simulated hydraulic heads through to the simulated SW-GW flux.

Estimated fluxes ranged between -1 and $2.5 \mathrm{~m}^{3} / \mathrm{m} /$ day (Figure 6). Upstream of the Campaspe Weir, gaining conditions yielded averaged flows from the Shepparton Formation to the river of $0.4 \mathrm{~m}^{3} / \mathrm{m} /$ day. Downstream of the Campaspe Weir, gaining conditions yielded averaged flows from the Shepparton to the river of $0.5 \mathrm{~m}^{3} / \mathrm{m} /$ day.

\section{Discussion}

Our investigation of SW-GW exchange flows at the regional scale included three commonly used techniques and aimed at comparing the estimated flows. Results show large discrepancies (Figure 7) both in flow directions and magnitudes. Indeed, upstream of the Campaspe Weir, the tracer mass balance model and the numerical model both indicate low gaining reaches whereas the Darcy flux calculation points to highly losing reaches. Although the three methods consistently show gaining reaches downstream of the Campaspe Weir, the numerical flow model and the Darcy flux calculation both resulted in slightly higher reach-averaged SW-GW exchange flows relative to the tracer mass balance approach. Based on these results, we hereafter discuss the information gained in terms of direction and magnitude of flows by each method as well as method advantages and limitations. We also evaluate consistent or alternative interpretations of SW-GW exchange flows along the river. 


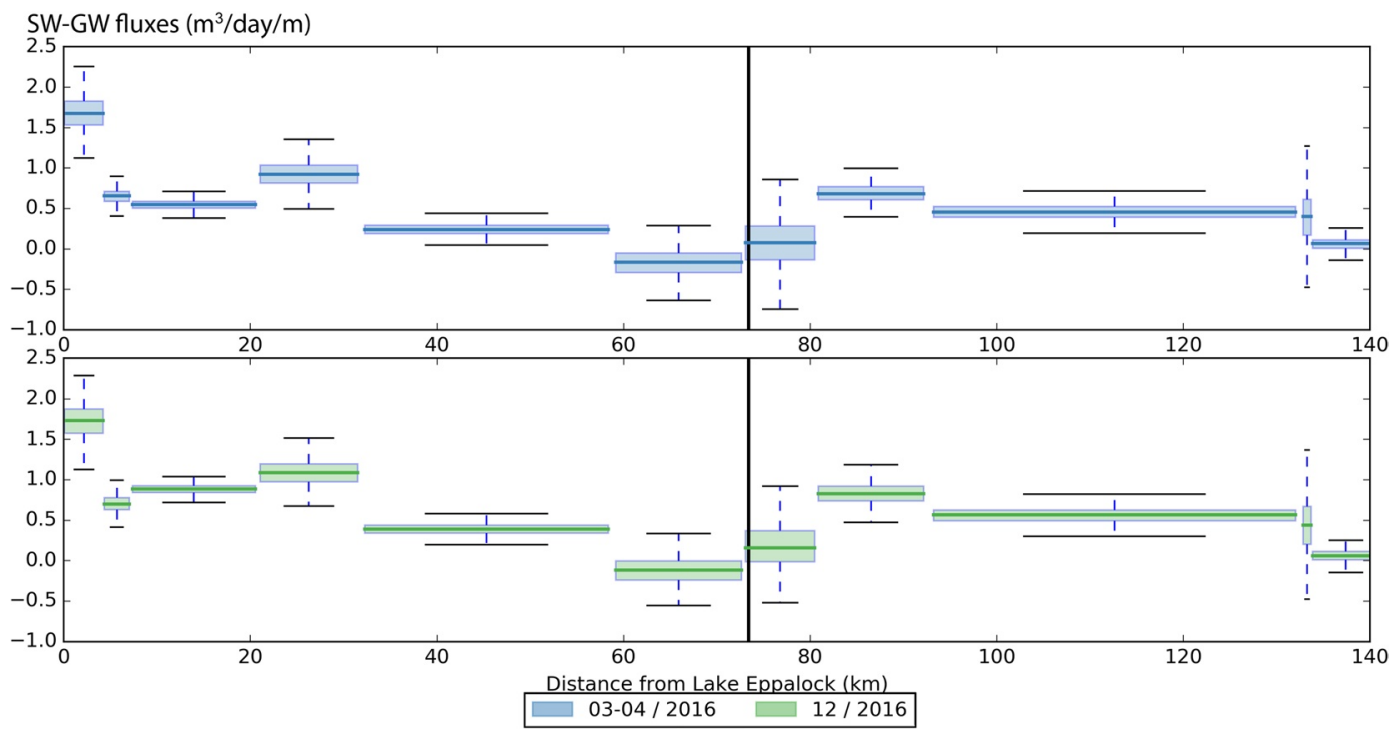

Figure 6. Distributions of SW-GW exchange fluxes (m3/m/day) derived from the numerical flow model (horizontal lines: median, boxes: interquartile ranges (IQR), whiskers: 1.5 times the IQR). SW-GW, surface water-groundwater.

\subsection{Direction of Flows}

Hydraulic heads allow determination of hydraulic gradients, and therefore we can assume that the direction of flows inferred by the Darcy flux method will be the most reliable. These results affirm previous studies indicating losing reaches in the upper part of the catchment and gaining reaches downstream (Wade, 2011). If groundwater heads are measured remotely from the river, the observed hydraulic gradient will represent time-averaged fluxes, which may be different from the SW-GW flux at any particular point in time. Nevertheless, it is noteworthy that the tracer mass balance model and the numerical model yield gaining flows in the upper part of the catchment, in direct contrast to the Darcy flux method.

As water losses do not alter river concentrations, the longitudinal tracer mass balance alone cannot estimate groundwater outflows, unless it is combined with a water balance based on accurate river flow data. In the current study, the estimated water inflows are likely due to an overestimation of the GTV or underestimation of hyporheic radon flux, or to local gains that are smaller than the reach-scale losses but that nevertheless modify tracer concentrations. In either case, the large unmonitored surface water pumping seriously limits the use of the tracer mass balance under losing conditions unless river flows are very accurately gauged.

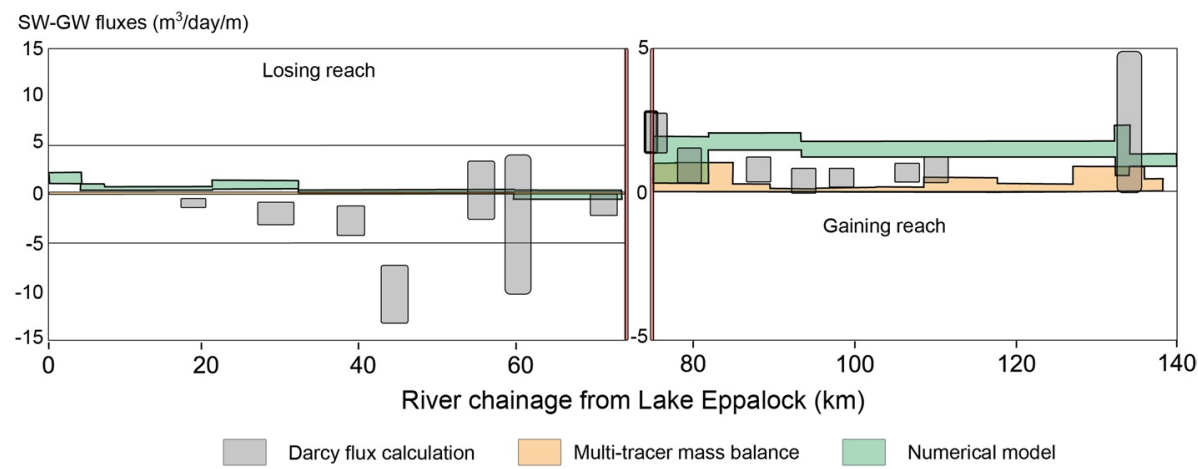

Figure 7. Comparison of SW-GW exchange flux estimates (m3/day/m) from the multi tracer mass balance (Figure 4), Darcy flux calculations (Figure 5) and the numerical model (Figure 6). Results are split into two subreaches, the losing reach upstream the Campaspe Weir and the gaining reach downstream, with different y-scales. Fluxes derived from tracer data in upstream areas are difficult to discern as they plot close to the X-axis. SW-GW, surface water-groundwater. 
However, given that the numerical model calculation of the SW-GW exchange flows in each reach includes data used by the Darcy flux approach, similar results both in direction and magnitude might be expected. Differences in the two approaches arise because the Darch approach calculates hydraulic gradient using the measured heads near the river, whereas the numerical model simulates groundwater heads throughout the catchment. Due to the complexity of the numerical flow model and the associated computational challenges, multiple sources of uncertainty can accumulate from model structure (Blasone et al., 2008), parametric uncertainty, errors in input data or the calibration process. For instance, recharge or evapotranspiration rates are difficult to estimate (Xie et al., 2018) particularly when intermittent recharge through irrigation occurs, such as in the Campaspe catchment. Systematic errors in these variables would yield large cumulative errors in catchment discharge, unless evenly and highly distributed data within the catchment allow the correction for this effect (Demissie et al., 2009; Refsgaard, 1997). Moreover, limited knowledge of river abstraction rates is problematic as this is an important parameter in the calibration of coupled SWGW numerical models. A data-worth study previously carried out on the Campaspe River using the same numerical model has indeed shown that under losing conditions, the model is very sensitive to recharge conditions and stream flows, while river chemical data do not significantly improve the calibration process (Partington et al., 2020). Therefore, in the present study, the availability of head data across the catchment is not sufficient to counter potential errors in recharge rates and stream flows, which cause the calibrated model to incorrectly predict the direction of SW-GW flows.

\subsubsection{Magnitude of Flows}

The three methods agree on flow directions for the gaining reaches but show differences of a factor of about 2 in flow magnitude. The longitudinal chemical mass balance was carried out with tracers sensitive to evaporation, hyporheic exchange fluxes and SW-GW exchange flows. Although each tracer has limitations, their combined use in a probabilistic approach together with the good model fits give confidence in the magnitudes and uncertainties of the estimated flows. Nevertheless, the results rely on strong assumptions such as spatially uniform groundwater concentrations, degassing rate and ${ }^{222} \mathrm{Rn}$ hyporheic flux along the 140km-long river. HZ exchange fluxes are known to vary over small-scales (Cardenas \& Markowski, 2011; Cartwright et al., 2014; Dudley-Southern \& Binley, 2015), and this is highlighted by the diversity of radon profiles measured in the hyporheic zone in our study. Degassing rates (Vautier et al., 2020) and the geochemistry of riparian groundwater can also vary over small spatial scales. While reach-averaged SW-GW exchange flow simulated with the tracer mass balance could be affected by local and rapid changes of these parameters, the uncertainties on the magnitude of flows are likely to be low as river chemistry is most sensitive to groundwater inputs.

The flow magnitudes derived from the Darcy approach are directly proportional to the hydraulic conductivity, which can vary spatially by several orders of magnitude and is complex to upscale. In the present study, the interpolation of $\mathrm{K}$ along the river, is based on limited data and is likely to yield large errors in the magnitude of flows, potentially up to several orders of magnitude. The Darcy flux method however allows for the evaluation of the temporal distribution of SW-GW flows in each reach. Therefore, while the magnitudes of flows derived from the Darcy method should be treated with caution, this method is an interesting way of identifying transient reaches.

Downstream of the Campaspe Weir, the calibration of the numerical model is likely to be better, as river chemical data used as part of the calibration informs SW-GW exchange flows under gaining conditions (Partington et al., 2020). The remaining discrepancies could result from the uncertainty sources previously discussed, and particularly to the lack of closure of water volumes in the system due to unmonitored water pumping not accounted for in the numerical model

\subsubsection{Synthesis on Method Comparison}

Previous method comparisons have been performed to evaluate SW-GW interactions on small catchments (Frei et al., 2009; Guay et al., 2013; Sulis et al., 2010), but the present study aimed at tackling the scientific lack of SW-GW exchange flow comparisons at regional scales (Barthel \& Banzhaf, 2016). Based on our results, the advantages and limitations of the three methods used in the present study are summarized (Table 2). The Darcy flux method is the most reliable for determining the direction and temporal variability of SW-GW flows, but high uncertainties are associated with the magnitude due to uncertain $\mathrm{K}$ 
Table 2

Limitations and Advantages of Method to Estimate SW-GW Flow Exchanges at a Regional Scale

\begin{tabular}{|c|c|c|}
\hline Method & Advantages & Limitations \\
\hline \multirow[t]{4}{*}{ Darcy flux } & Easily accessible data & $\begin{array}{l}\text { Limited by the density and location of available } \\
\text { monitoring piezometers and stream gauges }\end{array}$ \\
\hline & $\begin{array}{l}\text { Works equally well under losing and gaining } \\
\text { conditions }\end{array}$ & $\begin{array}{l}\text { Requires careful selection of appropriate } \\
\text { piezometers }\end{array}$ \\
\hline & $\begin{array}{l}\text { Robust assessment of hydraulic gradient, and thus } \\
\text { of flow direction }\end{array}$ & \\
\hline & Good estimate of the temporal variability of flows & $\begin{array}{l}\text { High uncertainties in flow magnitudes, because } \\
\text { of uncertainty in hydraulic conductivity at } \\
\text { large scales }(>\mathrm{km})\end{array}$ \\
\hline \multirow[t]{5}{*}{ Multitracer mass balance } & $\begin{array}{l}\text { Under gaining conditions, good estimate of flow } \\
\text { magnitude }\end{array}$ & Labor intensive in the field \\
\hline & $\begin{array}{l}\text { Can disentangle hyporheic exchange and } \\
\text { groundwater discharge }\end{array}$ & Point measurement in time \\
\hline & $\begin{array}{l}\text { Spatial and temporal resolution are determined by } \\
\text { the field-design }\end{array}$ & $\begin{array}{l}\text { Absolute flux estimates require accurate river flow } \\
\text { data }\end{array}$ \\
\hline & & Very sensitive to hyporheic flows \\
\hline & & Not suitable under losing conditions \\
\hline \multirow{2}{*}{$\begin{array}{l}\text { Coupled SW-GW numerical flow at catchment } \\
\text { scale }\end{array}$} & Ability to incorporate all field data & \multirow{2}{*}{$\begin{array}{l}\text { Under losing conditions, very sensitive to recharge } \\
\text { rates and flow data }\end{array}$} \\
\hline & $\begin{array}{l}\text { High spatial and temporal resolution of SW-GW } \\
\text { flux }\end{array}$ & \\
\hline
\end{tabular}

Abbreviation: SW-GW, surface water-groundwater.

values. The scale of applicability of local measurements depends on the subgrid scale of heterogeneity of the hydraulic conductivity, therefore upscaling local measurements to larger areas might yield errors in SW-GW estimates. For instance, preferential flow paths might be missed in this approach although they could potentially account for a large proportion of groundwater discharge to the river (Briggs \& Hare, 2018). The tracer mass balance, while not directly applicable under losing conditions, gives reliable estimates of groundwater inflows in gaining areas. However, hyporheic fluxes may strongly bias ${ }^{222} \mathrm{Rn}$ results as ${ }^{222} \mathrm{Rn}$ production within the hyporheic zone is hard to estimate. Because of the complexity of the hyporheic flow field, streambed vertical profiles are difficult to interpret (Vogt et al., 2010) and the significance of each vertical profiles in terms of solute inputs in the river is difficult to assess, which clearly limits the upscaling from local streambed vertical profiles to reach scale concentration profiles along rivers (Knapp et al., 2017). The regional calibration of the numerical model suffers from the limited distribution of head data and poorly constrained recharge and river abstraction fluxes. As a result, high uncertainties in the simulated groundwater heads near the river have repercussions for SW-GW exchange flows. This holds particularly true around losing river reaches, where the calibration is not sensitive to additional data such as river chemistry. Following (Bredehoeft, 2005), the model conceptualization together with the availability of data might yield large uncertainties on the estimation of SW-GW exchange flows, particularly under losing conditions.

The consistency of results in the gaining reaches improves confidence in the results and approaches, which might otherwise be uncertain. For all three methods, an accurate estimation of river abstraction stands out as crucial to evaluate SW-GW flow exchanges. This remains a large limitation as most of the world's rivers have been dammed with little monitoring, altering stream flows and biogeochemical cycling (Grill et al., 2019; Maavara et al., 2015).

\subsubsection{Interpretations of SW-GW Exchange Flows along the Campaspe River}

The spatial variability of SW-GW exchange flows along the Campaspe River can be quantitatively determined in the gaining reaches of the river, where the three methods best agree. Most of the groundwater inflows occurred in small river reaches. The highest gaining fluxes were found in the $10 \mathrm{~km}$ reaches downstream of Lake Eppalock and Campaspe Weir, in part illustrating the potential effect of high lake stages, 
controlled by dams, on the downstream groundwater flows. The gaining conditions observed downstream of the Campaspe Weir are also likely related to higher recharge rates due to intense irrigation in this area. In the Campaspe catchment, the strong river regulation not only influences stream flows, but also modifies the spatial distribution and the magnitude of SW-GW exchange fluxes along the river reach.

\section{Conclusions}

In the present study, SW-GW exchange flows were investigated along a $140 \mathrm{~km}$ long, highly regulated river reach in the Campaspe subcatchment of the Murray-Darling Basin, Australia. SW-GW exchange fluxes were quantified by a tracer mass balance, a Darcy flux calculation using near-river piezometers, and a regional surface-subsurface numerical flow model. Differences both in the directions and magnitudes of SW-GW exchange flows estimated along the $140 \mathrm{~km}$ long reach were found. In acknowledging that there is no direct measurement of SW-GW exchange available at the regional scale, the authors found application of the Darcy method the most reliable to estimate SW-GW flux directions and the tracer mass balance the most reliable to estimate SW-GW flux magnitudes in gaining reaches. Although the numerical model utilizes the same approach as the Darcy method, there is a mismatch as hydraulic head is a state variable rather than a parameter, leading to differences in the calculated exchange fluxes.

Ultimately, numerical flow models allow for a higher resolution of spatially and temporally varying groundwater head, stream stage and riverbed parameters and therefore of SW-GW exchange flows, which overcomes some of the spatial and temporal homogeneity assumptions associated with the tracer mass balance and the Darcy flux calculation. From a management point of view, regional scale numerical modeling is the only way to investigate the impact of land-use changes, water allocation changes, or climate change on SW-GW exchange flows, as the model forcing associated with such impacts (e.g., changes to recharge and pumping) is propagated through to the state variables (i.e., groundwater hydraulic head and stream stage) that control the SW-GW exchange flux. However, poor calibration of stream observation data in numerical models at the catchment scale might not allow reliable estimation of SW-GW exchange fluxes, as groundwater discharge values accumulate many sources of uncertainties.

The disagreement in outcomes here shows that modeling approaches remain limited by availability of accurate, high frequency and high resolution field data essential for a relevant calibration of numerical models to estimate SW-GW exchange fluxes. While high performance computing in hydrology makes numerical modeling easier to implement at high resolution and large scales, approaches to guide data collection strategies are crucial for informing and quantifying uncertainty and then in turn, the uncertainty reduction in model predictions. The benefit of using river chemistry data in the calibration process is here shown in gaining reaches.

\section{Data Availability Statement}

Field and modeling data used are available at https://doi.org/10.25957/5E7451E13D031.

Acknowledgments

This research was funded by the Murray-Darling Basin Authority through the MDBA-NCGRT Strategic Groundwater Research Partnership. The authors also thank the French Academy of Sciences and Labex OT-Med (Objectif Terre: Bassin Méditerranéen; http:// www.otmed.fr/) for the complementary financial support. We acknowledge Nicholas White, Saskia Noorduijn, Yueqing Xie, and David Poulsen for their assistance during fieldwork. We warmly thank the editor Xavier Sanchez-Vila, the associate editor Christine Hatch, Olaf A. Cirpka and two anonymous reviewers for their valuable comments that highly helped increasing the quality and clarity of our manuscript.

\section{References}

ABS. (2008). Water and the Murray-Darling Basin-a statistical profile, 2000-01 to 2005-06. Canberra, Australia: Australian Bureau of Statistics.

Arad, A., \& Evans, R. (1987). The hydrogeology, hydrochemistry and environmental isotopes of the Campaspe River aquifer system, North-Central Victoria, Australia. Journal of Hydrology, 95(1), 63-86. https://doi.org/10.1016/0022-1694(87)90116-8

Atkinson, A. P., Cartwright, I., Gilfedder, B. S., Hofmann, H., Unland, N. P., Cendón, D. I., \& Chisari, R. (2015). A multi-tracer approach to quantifying groundwater inflows to an upland river; assessing the influence of variable groundwater chemistry. Hydrological Processes, 29(1), 1-12. https://doi.org/10.1002/hyp.10122

Barthel, R., \& Banzhaf, S. (2016). Groundwater and Surface water interaction at the regional-scale-A review with focus on regional integrated models. Water Resources Management, 30(1), 1-32. https://doi.org/10.1007/s11269-015-1163-Z

Blasone, R.-S., Madsen, H., \& Rosbjerg, D. (2008). Uncertainty assessment of integrated distributed hydrological models using GLUE with Markov chain Monte Carlo sampling. Journal of Hydrology, 353(1), 18-32. https://doi.org/10.1016/j.jhydrol.2007.12.026

Bourke, S. A., Cook, P. G., Shanafield, M., Dogramaci, S., \& Clark, J. F. (2014). Characterisation of hyporheic exchange in a losing stream using radon-222. Journal of Hydrology, 519, 94-105. https://doi.org/10.1016/j.jhydrol.2014.06.057

Bredehoeft, J. (2005). The conceptualization model problem-Surprise. Hydrogeology Journal, 13(1), 37-46. https://doi.org/10.1007/ s10040-004-0430-5 
Briggs, M. A., \& Hare, D. K. (2018). Explicit consideration of preferential groundwater discharges as surface water ecosystem control points. Hydrological Processes, 32(15), 2435-2440. https://doi.org/10.1002/hyp.13178

Brunner, P., \& Cook, P. G. (2009). Hydrogeologic controls on disconnection between surface water and groundwater. Water Resources Research, 45(1), W01422. https://doi.org/10.1029/2008WR006953

Brunner, P., Cook, P. G., \& Simmons, C. T. (2011). Disconnected surface water and groundwater: From Theory to practice. Groundwater, 49(4), 460-467. https://doi.org/10.1111/j.1745-6584.2010.00752.x

Brunner, P., René, T., Philippe, R., Simmons Craig, T., \& Harrie-Jan Hendricks, F. (2017). Advances in understanding river-groundwater interactions. Reviews of Geophysics, 55(3), 818-854. https://doi.org/10.1002/2017RG000556

Brunner, P., \& Simmons, C. T. (2012). HydroGeoSphere: A Fully integrated, physically based hydrological model. Groundwater, 50(2), 170-176. https://doi.org/10.1111/j.1745-6584.2011.00882.x

Brunner, P., Simmons, C. T., Cook, P. G., \& Therrien, R. (2010). Modeling surface water-groundwater interaction with MODFLOW: Some considerations. Groundwater, 48(2), 174-180. https://doi.org/10.1111/j.1745-6584.2009.00644.x

Cardenas, M. B., \& Markowski, M. S. (2011). Geoelectrical imaging of hyporheic exchange and mixing of river water and groundwater in a large regulated river. Environmental Science \& Technology, 45(4), 1407-1411. https://doi.org/10.1021/es103438a

Cartwright, I. (2010). Using groundwater geochemistry and environmental isotopes to assess the correction of $14 \mathrm{C}$ ages in a silicate-dominated aquifer system. Journal of Hydrology, 382(1-4), 174-187. https://doi.org/10.1016/j.jhydrol.2009.12.032

Cartwright, I., \& Hofmann, H. (2016). Using radon to understand parafluvial flows and the changing locations of groundwater inflows in the Avon River, southeast Australia. Hydrology and Earth System Sciences, 20(9), 3581-3600. https://doi.org/10.5194/hess-20-3581-2016

Cartwright, I., Hofmann, H., Gilfedder, B., \& Smyth, B. (2014). Understanding parafluvial exchange and degassing to better quantify groundwater inflows using 222Rn: The King River, southeast Australia. Chemical Geology, 380, 48-60. https://doi.org/10.1016/j. chemgeo.2014.04.009

Cartwright, I., Hofmann, H., Sirianos, M. A., Weaver, T. R., \& Simmons, C. T. (2011). Geochemical and 222Rn constraints on baseflow to the Murray River, Australia, and timescales for the decay of low-salinity groundwater lenses. Journal of Hydrology, 405(3), 333-343. https://doi.org/10.1016/j.jhydrol.2011.05.030

Cartwright, I., \& Morgenstern, U. (2012). Constraining groundwater recharge and the rate of geochemical processes using tritium and major ion geochemistry: Ovens catchment, southeast Australia. Journal of Hydrology, 475, 137-149. https://doi.org/10.1016/j. jhydrol.2012.09.037

Cartwright, I., Weaver, T. R., \& Fifield, L. K. (2006). Cl/Br ratios and environmental isotopes as indicators of recharge variability and groundwater flow: An example from the southeast Murray Basin, Australia. Chemical Geology, 231(1-2), 38-56. https://doi.org/10.1016/j. chemgeo.2005.12.009

Cook, P. G. (2013). Estimating groundwater discharge to rivers from river chemistry surveys. Hydrological Processes, $27(25), 3694-3707$. https://doi.org/10.1002/hyp.9493

Cook, P. G. (2015). Quantifying river gain and loss at regional scales. Journal of Hydrology, 531(3), 749-758. https://doi.org/10.1016/j. jhydrol.2015.10.052

Cook, P. G., Favreau, G., Dighton, J. C., \& Tickell, S. (2003). Determining natural groundwater influx to a tropical river using radon, chlorofluorocarbons and ionic environmental tracers. Journal of Hydrology, 277(1), 74-88. https://doi.org/10.1016/S0022-1694(03)00087-8

Cook, P. G., Lamontagne, S., Berhane, D., \& Clark, J. F. (2006). Quantifying groundwater discharge to Cockburn River, southeastern Australia, using dissolved gas tracers 222Rn and SF6. Water Resources Research, 42(10), W10411. https://doi.org/10.1029/2006WR004921

Cook, P. G., Rodellas, V., Andrisoa, A., \& Stieglitz, T. C. (2018). Exchange across the sediment-water interface quantified from porewater radon profiles. Journal of Hydrology, 559, 873-883. https://doi.org/10.1016/j.jhydrol.2018.02.070

Craig, H., \& Gordon, L. I. (1965). Deuterium and oxygen-18 variations in the ocean and marine atmospheres. In E. Tongiorgi (Ed.), Stable isotopes in oceanographic studies and paleotemperatures (pp. 9-130). Pisa, Italy: Lischi and Figli.

Cranswick, R. H., \& Cook, P. G. (2015). Scales and magnitude of hyporheic, river-aquifer and bank storage exchange fluxes. Hydrological Processes, 29(14), 3084-3097. https://doi.org/10.1002/hyp.10421

Cranswick, R. H., Cook, P. G., \& Lamontagne, S. (2014). Hyporheic zone exchange fluxes and residence times inferred from riverbed temperature and radon data. Journal of Hydrology, 519, 1870-1881. https://doi.org/10.1016/j.jhydrol.2014.09.059

Crosbie, R. (2012). New insights to the chemical and isotopic composition of rainfall across Australia (WATER FOR A HEALTHY COUNTRY FLAGSHIP) (p. 86). CSIRO.

Darcy, H. (1856). Les fontaines publiques de la ville de Dijon: Exposition et application. Victor Dalmont.

Demissie, Y. K., Valocchi, A. J., Minsker, B. S., \& Bailey, B. A. (2009). Integrating a calibrated groundwater flow model with error-correcting data-driven models to improve predictions. Journal of Hydrology, 364(3), 257-271. https://doi.org/10.1016/j.jhydrol.2008.11.007

Doherty, J. (2016). PEST model-independent parameter estimation user manual part I: PEST. SENSAN and Global Optimisers.

Dudley-Southern, M., \& Binley, A. (2015). Temporal responses of groundwater-surface water exchange to successive storm events. Water Resources Research, 51(2), 1112-1126. https://doi.org/10.1002/2014WR016623

Fleckenstein, J. H., Krause, S., Hannah, D. M., \& Boano, F. (2010). Groundwater-surface water interactions: New methods and models to improve understanding of processes and dynamics. Advances in Water Resources, 33(11), 1291-1295. https://doi.org/10.1016/j. advwatres.2010.09.011

Frei, S., Fleckenstein, J. H., Kollet, S. J., \& Maxwell, R. M. (2009). Patterns and dynamics of river-aquifer exchange with variably-saturated flow using a fully-coupled model. Journal of Hydrology, 375(3), 383-393. https://doi.org/10.1016/j.jhydrol.2009.06.038

Gibson, J. J., \& Edwards, T. W. D. (2002). Regional water balance trends and evaporation-transpiration partitioning from a stable isotope survey of lakes in northern Canada. Global Biogeochemical Cycles, 16(2), 10-11. https://doi.org/10.1029/2001GB001839

González-Pinzón, R., Ward, A. S., Hatch, C. E., Wlostowski, A. N., Singha, K., Gooseff, M. N., et al. (2015). A field comparison of multiple techniques to quantify groundwater-surface-water interactions. Freshwater Science, 34(1), 139-160. https://doi.org/10.1086/679738

Grill, G., Lehner, B., Thieme, M., Geenen, B., Tickner, D., Antonelli, F., et al. (2019). Mapping the world's free-flowing rivers. Nature, 569(7755), 215-221. https://doi.org/10.1038/s41586-019-1111-9

Guay, C., Nastev, M., Paniconi, C., \& Sulis, M. (2013). Comparison of two modeling approaches for groundwater-surface water interactions. Hydrological Processes, 27(16), 2258-2270. https://doi.org/10.1002/hyp.9323

Harvey, J. W., Böhlke, J. K., Voytek, M. A., Scott, D., \& Tobias, C. R. (2013). Hyporheic zone denitrification: Controls on effective reaction depth and contribution to whole-stream mass balance. Water Resources Research, 49(10), 6298-6316. https://doi.org/10.1002/wrcr.20492

Herczeg, A. L., Dighton, J. C., Easterbrook, M. L., \& Salomons, E. (1994). Radon-222 and Ra-226 measurements in Australian groundwaters using liquid scintillation counting. In R. A. Akber \& F. Harris (Eds.), Proceeding of Workshop on Radon and Radon Progeny Measurements in Environmental Samples (pp. 53-57). Canberra: Off. of the Supervis. Sci. 
Horita, J., Rozanski, K., \& Cohen, S. (2008). Isotope effects in the evaporation of water: a status report of the Craig-Gordon model. Isotopes in Environmental and Health Studies, 44(1), 23-49. https://doi.org/10.1080/10256010801887174

Houska, T., Kraft, P., Chamorro-Chavez, A., \& Breuer, L. (2015). SPOTting model parameters using a ready-made python package. PloS One, 10(12), e0145180. https://doi.org/10.1371/journal.pone.0145180

Kalbus, E., Reinstorf, F., \& Schirmer, M. (2006). Measuring methods for groundwater-Surface water interactions: a review. Hydrology and Earth System Sciences, 10(6), 873-887. https://doi.org/10.5194/hess-10-873-2006

Kiel, B. A., \& Cardenas, M. B. (2014). Lateral hyporheic exchange throughout the Mississippi River network. Nature Geoscience, 7(6), 413-417. https://doi.org/10.1038/ngeo2157

Knapp, J. L. A., González-Pinzón, R., Drummond, J. D., Larsen, L. G., Cirpka, O. A., \& Harvey, J. W. (2017). Tracer-based characterization of hyporheic exchange and benthic biolayers in streams. Water Resources Research, 53(2), 1575-1594. https://doi.org/10.1002/2016WR019393

Lamontagne, S., \& Cook, P. G. (2007). Estimation of hyporheic water residence time in situ using 222Rn disequilibrium. Limnology and Oceanography: Methods, 5(11), 407-416. https://doi.org/10.4319/lom.2007.5.407

Lamontagne, S., Taylor, A. R., Cook, P. G., Crosbie, R. S., Brownbill, R., Williams, R. M., \& Brunner, P. (2014). Field assessment of surface water-groundwater connectivity in a semi-arid river basin (Murray-Darling, Australia). Hydrological Processes, 28(4), 1561-1572. https://doi.org/10.1002/hyp.9691

Leaney, F. W., \& Herczeg, A. L. (2006). A rapid field extraction method for determination of radon-222 in natural waters by liquid scintillation counting. Limnology and Oceanography: Methods, 4(7), 254-259. https://doi.org/10.4319/lom.2006.4.254

Maavara, T., Parsons, C. T., Ridenour, C., Stojanovic, S., Dürr, H. H., Powley, H. R., \& Cappellen, P. V. (2015). Global phosphorus retention by river damming. Proceedings of the National Academy of Sciences, 112(51), 15603-15608. https://doi.org/10.1073/pnas.1511797112

Majoube, M. (1971). Fractionnement en oxygène 18 et en deutérium entre l'eau et sa vapeur. Journal de Chimie Physique, 68, 1423-1436. https://doi.org/10.1051/jcp/1971681423

Martin, J. B. (2007). Cable Jaye E., Smith Christopher, Roy Moutusi, \& Cherrier Jennifer.Magnitudes of submarine groundwater discharge from marine and terrestrial sources: Indian River Lagoon, Florida. Water Resources Research, 43(5), W05440. https://doi. org/10.1029/2006WR005266

McCallum, J. L., Cook, P. G., Brunner, P., \& Berhane, D. (2010). Solute dynamics during bank storage flows and implications for chemical base flow separation. Water Resources Research, 46(7), W07541. https://doi.org/10.1029/2009WR008539

Negulescu, M., \& Rojanski, V. (1969). Recent research to determine reaeration coefficient. Water Research, 3(3), 189-202. https://doi. org/10.1016/0043-1354(69)90058-X

Niswonger, R. G., Panday, S., \& Ibaraki, M. (2011). MODFLOW-NWT, A Newton formulation for MODFLOW-2005. U.S. Geological Survey Techniques and Methods 6-A37. Reston, Virginia: USGS.

Noorduijn, S. L., Shanafield, M., Trigg, M. A., Harrington, G. A., Cook, P. G., \& Peeters, L. (2014). Estimating seepage flux from ephemeral stream channels using surface water and groundwater level data. Water Resources Research, 50(2), 1474-1489. https://doi. org/10.1002/2012WR013424

O'Connor, D. J., \& Dobbins, W. E. (1956). The Mechanics of Reaeration in Natural Streams. Journal of the Sanitary Engineering Division, $82(6), 1-30$

Parsons, S., Hoban, M., \& Evans, R. (2008). Surface-groundwater connectivity assessment: A report to the Australian Government from the CSIRO Murray-Darling Basin sustainable yields project (Vol. 35). CSIRO Canberra.

Partington, D., Brunner, P., Simmons, C. T., Therrien, R., Werner, A. D., Dandy, G. C., \& Maier, H. R. (2011). A hydraulic mixing-cell method to quantify the groundwater component of streamflow within spatially distributed fully integrated surface water-groundwater flow models. Environmental Modelling \& Software, 26(7), 886-898. https://doi.org/10.1016/j.envsoft.2011.02.007

Partington, D., Knowling, M. J., Simmons, C. T., Cook, P. G., Xie, Y., Iwanaga, T., \& Bouchez, C. (2020). Worth of hydraulic and water chemistry observation data in terms of the reliability of surface water-groundwater exchange flux predictions under varied flow conditions. Journal of Hydrology, 590, 125441. https://doi.org/10.1016/j.jhydrol.2020.125441

Refsgaard, J. C. (1997). Parameterisation, calibration and validation of distributed hydrological models. Journal of Hydrology, 198(1), 69-97. https://doi.org/10.1016/S0022-1694(96)03329-X

Semenova, O., \& Beven, K. (2015). Barriers to progress in distributed hydrological modelling: Invited commentary. Hydrological Processes, 29(8), 2074-2078. https://doi.org/10.1002/hyp.10434

Sophocleous, M. (2002). Interactions between groundwater and surface water: the state of the science. Hydrogeology Journal, $10(1), 52-67$. https://doi.org/10.1007/s10040-001-0170-8

Sulis, M., Meyerhoff, S. B., Paniconi, C., Maxwell, R. M., Putti, M., \& Kollet, S. J. (2010). A comparison of two physics-based numerical models for simulating surface water-groundwater interactions. Advances in Water Resources, 33(4), 456-467. https://doi.org/10.1016/j. advwatres.2010.01.010

Swanson, R. D., Binley, A., Keating, K., France, S., Osterman, G., Day-Lewis, F. D., \& Singha, K. (2015). Anomalous solute transport in saturated porous media: Relating transport model parameters to electrical and nuclear magnetic resonance properties. Water Resources Research, 51(2), 1264-1283. https://doi.org/10.1002/2014WR015284

Vautier, C., Abhervé, R., Labasque, T., Laverman, A. M., Guillou, A., Chatton, E., et al. (2020). Mapping gas exchanges in headwater streams with membrane inlet mass spectrometry. Journal of Hydrology, 581, 124398. https://doi.org/10.1016/j.jhydrol.2019.124398

Vogt, T., Hoehn, E., Schneider, P., Freund, A., Schirmer, M., \& Cirpka, O. A. (2010). Fluctuations of electrical conductivity as a natural tracer for bank filtration in a losing stream. Advances in Water Resources, 33(11), 1296-1308. https://doi.org/10.1016/j.advwatres.2010.02.007

Vrugt, J. A., \& Braak, C. J. F. T. (2011). DREAM(D): an adaptive Markov Chain Monte Carlo simulation algorithm to solve discrete, noncontinuous, and combinatorial posterior parameter estimation problems. Hydrology and Earth System Sciences, 15, 3701-3713. https:// doi.org/10.5194/hess-15-3701-2011

Wade, A. (2011). Groundwater-surface water interaction in the lower Campaspe Valley water supply protection area. Aquade Groundwater Services.1-62.

Wöhling, T., Gosses, M. J., Wilson, S. R., \& Davidson, P. (2018). Quantifying River-Groundwater Interactions of New Zealand's Gravel-Bed Rivers: The Wairau Plain. Groundwater, 56(4), 647-666. https://doi.org/10.1111/gwat.12625

Xie, Y., Cook, P. G., \& Simmons, C. T. (2016). Solute transport processes in flow-event-driven stream-aquifer interaction. Journal of Hydrology, 538, 363-373. https://doi.org/10.1016/j.jhydrol.2016.04.031

Xie, Y., Cook, P. G., Simmons, C. T., Partington, D., Crosbie, R., \& Batelaan, O. (2018). Uncertainty of groundwater recharge estimated from a water and energy balance model. Journal of Hydrology. 561, 1081-1093. https://doi.org/10.1016/j.jhydrol.2017.08.010 